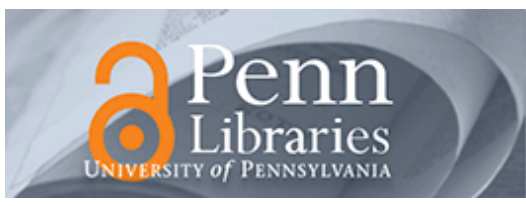

University of Pennsylvania ScholarlyCommons

Wharton Pension Research Council Working

Papers

Wharton Pension Research Council

$5-1-2000$

\title{
Accounting/Actuarial Bias Enables Equity Investment by Defined Benefit Pension Plans
}

Jeremy Gold

Jeremy Gold Pensions

Follow this and additional works at: https://repository.upenn.edu/prc_papers

Part of the Economics Commons

Gold, Jeremy, "Accounting/Actuarial Bias Enables Equity Investment by Defined Benefit Pension Plans" (2000). Wharton Pension Research Council Working Papers. 462.

https://repository.upenn.edu/prc_papers/462

This paper is posted at ScholarlyCommons. https://repository.upenn.edu/prc_papers/462

For more information, please contact repository@pobox.upenn.edu. 


\title{
Accounting/Actuarial Bias Enables Equity Investment by Defined Benefit Pension Plans
}

\begin{abstract}
Although pension finance theory says almost all defined benefit pension plans sponsored by publicly traded U.S. corporations should invest entirely in fixed income, $60 \%$ of assets are invested in equities. I offer a variation on the existing theory, removing the strong, but often unstated, assumption of transparency. The transparent (financial) model assumes that investors and managers view the pension plan as a portfolio of marketed assets and liabilities, a subsidiary of the operating parent, and subject to arbitrage. An opaque model holds that investors and managers view the plan in operating (accounting/actuarial) terms and value it based on earnings considerations. Defined benefit pension plans earnings (expense) are computed using actuarial methods and economic assumptions that systematically anticipate expected equity returns and strongly dampen the volatility of actual equity returns. Thus, corporations whose plans invest in equity overstate the financial value of their earnings and understate the volatility of such earnings. Under the transparent model, managers who invest in equities may be confronted by arbitrage arguments that show equity investment injures shareholders. Under the opaque model, these arbitrage arguments are not available and managers who invest in equities enjoy premium returns to risk while those who invest in fixed income are punished by higher costs with no apparent risk reduction.
\end{abstract}

\section{Disciplines \\ Economics}




\title{
Accounting/Actuarial Bias Enables Equity Investment by Defined Benefit Pension Plans
}

\author{
Jeremy Gold \\ PRC WP 2001-5 \\ May 2000 \\ Pension Research Council Working Paper \\ Pension Research Council \\ The Wharton School, University of Pennsylvania \\ 3641 Locust Walk, 304 CPC \\ Philadelphia, PA 19104-6218 \\ Tel: (215) 898-0424 • Fax: (215) 898-0310 \\ http://prc.wharton.upenn.edu/prc/prc.html
}

Pension Research Council Working Papers are intended to make research findings available to other researchers in preliminary form, to encourage discussion and suggestions for revision before final publication. Opinions are solely those of the authors.

(C2001 Pension Research Council of the Wharton School of the University of Pennsylvania. All Rights Reserved. 


\section{Accounting/Actuarial Bias Enables Equity Investment by Defined Benefit Pension Plans}

Abstract 1

I Introduction 1

Contrasting views of pension liabilities - financial vs. actuarial 2

Contrasting views - financial 3

Contrasting views - actuarial $\quad 5$

$\begin{array}{ll}\text { Remaining Sections } & 7\end{array}$

II $\quad$ Opaque Model Encourages Mispricing 8

Contrast: finance and accounting 8

Accounting: earnings and balance sheet. Finance: returns and value 9

A thought experiment 10

How pensions compare/contrast with the thought experiment 12

III Model Approach 13

Assumptions 13

Definitions 13

IV Pension Subsidiary Model $\quad 15$

$\begin{array}{ll}\text { Structure } & 15\end{array}$

$\begin{array}{ll}\text { Interactions } & 16\end{array}$

$\begin{array}{ll}\text { Costs - financial model } & 16\end{array}$

Costs - actuarial/accounting model 18

Costs - actuarial/accounting bias 21

Value of the cost bias 22

V Supporting Considerations $\quad 23$

Transparent accounting 24

Opacity enables fables - practictioners' tales 25

Transparency disables fables $\quad 27$

Accounting literature 28

Earnings-management literature shows investors act on reported earnings $\quad 31$

The FASB process -yesterday, today and tomorrow 33

VI Counter Arguments 37

SFAS 87 expected returns on assets do not fully adjust for equity premia $\quad 37$

SFAS 87 disclosures are sufficient to approximate transparent expense 38

Multi-year beta 
VIII Persistent Mispricing

IX Conclusions

Appendices

A Statement No. 87 of the Financial Accounting Standards Board (FAS 87), Accounting for Pensions by Employers

B Excise Taxes on Assets Reverted to Plan Sponsors 49

C PBGC Put and Excise Tax Call $\quad 50$

D Actuarial Standard of Practice No. 27, Selection of Economic Assumptions for Measuring Pension Obligations 


\title{
Biased Methodology Enables Equity Investment by Defined Benefit Pension Plans
}

\begin{abstract}
Although pension finance theory says almost all defined benefit pension plans sponsored by publicly traded U.S. corporations should invest entirely in fixed income, $60 \%$ of assets are invested in equities. I offer a variation on the existing theory, removing the strong, but often unstated, assumption of transparency. The transparent (financial) model assumes that investors and managers view the pension plan as a portfolio of marketed assets and liabilities, a subsidiary of the operating parent, and subject to arbitrage. An opaque model holds that investors and managers view the plan in operating (accounting/actuarial) terms and value it based on earnings considerations.

Defined benefit pension plans earnings (expense) are computed using actuarial methods and economic assumptions that systematically anticipate expected equity returns and strongly dampen the volatility of actual equity returns. Thus, corporations whose plans invest in equity overstate the financial value of their earnings and understate the volatility of such earnings.

Under the transparent model, managers who invest in equities may be confronted by arbitrage arguments that show equity investment injures shareholders. Under the opaque model, these arbitrage arguments are not available and managers who invest in equities enjoy premium returns to risk while those who invest in fixed income are punished by higher costs with no apparent risk reduction.
\end{abstract}

\section{Introduction}

Although pension finance theory says almost all defined benefit pension plans sponsored by publicly traded U.S. corporations should invest entirely in fixed income, in fact $60 \%$ of assets are invested in equities ${ }^{1}$. This dissonance is not a small matter. The $\$ 3$ trillion of pension equity investments represents about $1 / 4$ of the U.S. equity market capitalization. Nor is it a transient issue. The equity percentage has been stable for the past 30 years even as changes in pertinent accounting, funding and tax laws have strengthened the pension finance arguments for fixed income.

$1 \quad$ Pensions and Investments, January 24, 2000. 
Pension finance theory has always embedded a strong, but often unstated, transparency assumption. The defined benefit plan is generally modeled as a transparent financial subsidiary of the sponsoring corporation. It is assumed that corporate managers, financial analysts and shareholders will see the plan this way and act accordingly.

This paper outlines a theory based on a translucent model wherein the financial aspects of the subsidiary are filtered through an actuarial screen.

\section{Contrasting views of pension liabilities - financial vs. actuarial}

There is a stark and important difference between the actuarial and the financial pricing principles as applied to defined benefit pension plans sponsored by publicly traded U.S. corporations. The actuarial principles, embodied in several documents':

- use the expected return on plan assets to calculate plan costs (thereby anticipating returns to risk before the risk is borne), and

- spread deviations from the expectation over several years.

The financial principles, based on pricing by arbitrage, determine the discount rate on the liabilities by reference to publicly traded hedging assets. These hedging assets closely match the liability cash flows with respect to maturities and creditworthiness and have similar correlations with the market portfolio (beta). For the (not so) special case where the liabilities are independent of the market portfolio and are collateralized and/or insured, liabilities may be discounted using the term structure of riskless interest rates.

Prior to the 1960's, the great majority of pension plans was "insured" by which I mean that life insurance companies took premiums from pension plan sponsors and promised deferred annuities to plan participants. Trowbridge (1952) summarized the actuarial methods that could be used by insurance companies and others to provide sufficient funds to meet the annuity obligations. The applicability of these methods to noninsurance entities allowed plan sponsors to elect to self-insure rather than buy their annuities. Plan sponsors who chose this route established pension trusts to act as

2 E.g., ASOP 27, FAS 87, IRC Section 412(c)3B, Trowbridge \& Farr (1976), Chapter 10. 
repositories for the plan assets and to pay beneficiaries, employed independent actuaries to perform periodic valuations of the plans, and hired money managers to see to the investment of the plan assets. Such plans are called "trusteed" instead of insured.

\section{Contrasting views - financial}

The trusteed plan has been interpreted by the financial community as a transparent financial subsidiary of the sponsoring corporation (Treynor, as Bagehot, 1972). Consistent with this perspective, Treynor proposed the "augmented balance sheet" as a model of the plan sponsor consolidated with its pension subsidiary. Subsequent pension finance research has generally relied on this model.

Sharpe (1976) observes that the establishment, by ERISA ${ }^{3}$, of the Pension Benefit Guaranty Corporation (PBGC) creates a put option for pension plans which may be exercised (with restrictions) ${ }^{4}$ to the advantage of the plan and the corporation when plan liabilities exceed plan assets. This put value may be maximized by minimizing contributions to the plan and by investing in equities.

Black (1980) and Tepper (1981) focus on the discrepant tax rules applied to the plan, the corporation and its shareholders. They conclude that tax benefits are maximized by maximizing tax-deductible contributions and by investing in fixed income.

Harrison and Sharpe (1983) demonstrate that the apparent tension between the pension put and the tax-arbitrage theories will lead to corner solutions (all-equity or all-fixed) depending on the pertinent variables in each corporation.

During the period 1985 through $1990^{5}$, Congress passed a number of laws that reduced the importance of the PBGC put option ${ }^{6}$ for the vast majority of employers and instituted

3 P.L. 93-406, Employee Retirement Income Security Act of 1974.

4 Ippolito and Boyce (1999) state that the PBGC, from its inception, required coincident sponsor bankruptcy. The Pension Protection Act (contained in P.L. 100-203, the Omnibus Budget Reconciliation Act of 1987) amended ERISA to make this position statutorily clear.

5 Including: the Single Employer Pension Plan Amendments Act (SEPPAA, contained in P.L. 99-272, The Consolidated Omnibus Budget Reconciliation Act of 1985), the Tax Reform Act of 1986, the Omnibus Budget Reconciliation Act of 1987 and the Omnibus Budget Reconciliation of 1990.

6 By requiring accelerated funding and higher PBGC premiums for poorly funded plans, by removing the $30 \%$ net worth cap on employer liability, and by the imposition of excise tax 
a confiscatory excise tax on the reversion of excess plan assets (overfunding) upon plan termination. The excise tax may be characterized as a call option ${ }^{7}$ held by the federal government against plans that accumulate assets substantially in excess of liabilities. The diminished role of the PBGC put and the existence of the "excise tax call" means that almost every major defined benefit plan today should be, per Harrison and Sharpe, invested entirely in fixed income.

Bulow and Scholes (1983) and Bodie (1991) observe that employees may hold implicit call options on well funded plans. These call options, just like the excise tax, discourage equity investment by defined benefit plans.

By 1983, transparent financial analysis of defined benefit pension plans demonstrated that the inclusion of equities among plan assets was costly to shareholders for the great majority of corporate pension plans. Since 1983, numerous changes to the Internal Revenue Code have made this result far stronger. Nonetheless, most corporate plans have continued to allocate substantial fractions of their assets to equities.

Friedman (1983) and Bodie et al (1987) conducted empirical studies to assess the degree to which actual pension fund management is integrated with corporate financial management (e.g., the theories identified above) in contrast to a null hypothesis (plan decisions are independent of the corporate financial status of the plan sponsor). They find that corporate finance does influence pension finance but not necessarily in the fashion theorized.

Friedman:

The unifying overall conclusion from the data is that United States corporations do not manage the pension plans which they sponsor as if these plans had nothing to do the corporation. Different responses appear to characterize firms' behavior in different contexts, but the evidence persistently indicates clear relationships between decisions about pension assets and liabilities and decisions about the other assets and liabilities of the firm. At the same time, the pattern of these relationships is, more often than not, inconsistent with familiar hypotheses

penalties for failure to meet minimum funding standards. Amir \& Benartzi (1999) state that the value of the put option has been substantially reduced and is now of second-order nature. 7 Appendix C. 
that have emerged thus far in the theoretical literature analyzing pension aspects of corporate finance.

Bodie et al distinguish the "traditional" from the "corporate financial" perspective:

Viewed from what we shall call the "traditional perspective," pension funds are entirely separate from the corporation and its shareholders and should be managed without regard to either corporate financial policy or the interests of the corporation and its shareholders.

... academic theorists have built an alternative perspective from which pension decisions are viewed as an integral part of overall corporate financial policy. From this perspective, defined benefit liabilities are just one more set of fixed financial liabilities of the firm. Pension assets, while collateral for the liabilities, are really just assets of the firm in that the surplus/deficit belongs to the firm's shareholders. This integrated perspective is then concerned with how to manage the firm's extended balance sheet, including both its normal assets and liabilities and its pension assets and liabilities, in the best interests of the shareholders.

Friedman, Bodie et al and all the subsequent empirical literature have found that equity remains an asset class favored by pension plans. It is clear that practitioners are not marching to the beat of the theoretical drummers.

\section{Contrasting views - actuarial}

Sponsors who insured their pension plans bought group deferred annuities. The premiums paid each year were deducted from corporate income. Then ${ }^{8}$, even more than now, insurers invested in high quality fixed income assets and interest rates were generally stable. Thus costs were inherently smooth from year to year for stable employee populations and insurers managed the process to reduce what little natural volatility there was.

When sponsors switched to trusteed plans, they treated the money contributed to the trust just as they had earlier treated the premiums paid to the insurance company; they deducted it from operating income each year. The actuaries that advised the plan sponsors employed actuarial cost methods that were designed to emphasize smooth year-to-year progressions of plan contributions/expense. As the percentage of the plan

\footnotetext{
$8 \quad$ ACLI Life Insurance Fact Book (1998), Table 6.9.
} 
assets invested in equities grew from $17 \%$ in 1952 to $55 \%$ in $1970^{\circ}$, actuaries strengthened their smoothing techniques ${ }^{10}$.

In 1966, the Accounting Principles Board (APB), predecessor to the Financial Accounting Standards Board (FASB), adopted Opinion 8 (APB 8) which, with only minor constraints, endorsed the idea that the cash contributed to the plan was the proper amount to reflect on company books of account.

This general identity of cash contributions and reported expense remained the norm until the FASB adopted Statement of Financial Standards No. 87 (SFAS 87) in December, 1985, and required its application to plan years beginning after December 15, 1986. SFAS 87 broke the tight bond between plan contributions and expense and significantly tightened the rules with respect to the selection of actuarial assumptions. Despite these improvements, SFAS 87 formalized and endorsed a systemic financial bias embedded in all pension actuarial methods. This bias derives from the anticipation of expected equity returns and the smoothing of equity volatility.

In financial terms, SFAS 87 overstates reported earnings because it reduces current expense by the expected return on risky assets in advance of the risk. SFAS 87 also smoothes earnings by amortizing deviations between expected and actual returns over forward periods. The combined effect of anticipating returns and smoothing deviations is so powerful that the resulting pension income (expense) is entirely uncorrelated with the contemporaneous market portfolio -- i.e., when we look upon the pension plan as a portfolio of assets and liabilities, we find that the returns (pension income or expense) on this portfolio appear to have a CAPM beta of zero no matter the equity allocation. ${ }^{11}$

If accounting for pension plans followed the financial economics model, the ideas of the pension finance theorists would find a ready audience. With a transparent accounting base, financial writers in the popular media would be able to understand and to explain the issues that would then cause rational investors to discredit equity investment by pension plans.

Ibid., Table 2.18.

Dreher(1960) and Hamilton, Jackson (1968)

Section VI modifies this assertion for longer measurement periods. 
The overstatement of corporate earnings associated with pension plan equity investments provides an incentive for managers to invest in equities. It is likely, however, that the incentive does not have a direct role; nor are managers necessarily aware of the earnings bias. Rather it is the case that the bias: 1) reinforces managers' beliefs about the benefits of equities for the long run, and 2) defeats (through opacity) the rational objections that would cause capital markets to correct the managers' behavior (and beliefs). Thus it may be said that the bias does not cause the equity investments, rather it enables them. This theory of bias, opacity and enablement explains observed practitioner behavior. It continues the integrated financial management concept but removes the transparency assumption of the earlier theory.

Corporate financial managers are highly motivated to report good earnings. The earnings management literature ${ }^{12}$ shows that persistent earnings are valued highly by investors and this is an incentive for managers to use their discretion in pursuit of smoothness. It is evident that SFAS 87 which overstates and smoothes earnings derived from pension plan equity investments will, if not penetrated by analysts, upwardly bias valuations by investors. The accounting view with respect to the value of smoothing has a financial counterpart: ceteris paribus, undetected smoothing of the returns on a portfolio will generally reduce CAPM beta and upwardly bias valuations by investors.

\section{Remaining Sections}

In Section II we further develop the finance versus accounting issue and its impact on investors. We include a thought experiment which shows how anticipating and smoothing returns biases valuation. In Section III we specify the assumptions and develop the corporate structure that drives the model of Section IV. The model of Section IV begins by valuing the pension plan subsidiary as a marketed portfolio of assets and liabilities. We show how this may be reformulated to produce the SFAS 87 pension expense equation and how the resulting bias is injected. Section $V$ begins with a description of transparent accounting and then develops support for my opacity thesis which asserts that the capital markets neither penetrate the actuarial veil nor correct

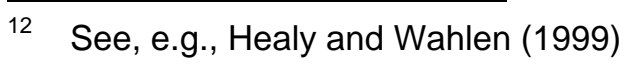


managers who invest their pension plans in equity. Section VI looks at counter arguments some of which weaken the opaque model and lead to a translucent middle ground. Section VII proposes an empirical framework for testing the degree of translucency and thus the merits of the opacity argument. Section VIII addresses how mispricing based on the opaque model can persist. Section IX concludes.

\section{Opaque Model Encourages Mispricing}

\section{Contrast: finance and accounting}

Finance focuses on the capital markets and the securities that are traded therein. Because the right-hand side of corporate balance sheets represent items that either are, or highly resemble, securities, it is natural for finance to model corporations as portfolios.

This view does not translate so well to the left-hand side of corporate balance sheets where market values are not so evident. Over time, however, the capital markets have been able to reconstitute some business assets in more security-like forms (e.g., saleleasebacks). A lease is more amenable to financial analysis than is a factory. Despite such activities, it will be quite some time, if ever, before the portfolio view of business permits any convergence between accounting and finance.

Some entities, however, are inherently more amenable to this portfolio view than are others. The most amenable are, not surprisingly, financial entities. Among the financials, the most naturally transparent and market-value-able are mutual funds and similar portfolio pass-throughs such as asset-backed securities, repackaged asset vehicles and defined contribution pension plans. Not quite so readily transparent, but certainly potentially subject to the market value portfolio view are banks, insurance companies and defined benefit pension plans.

A special problem presented by defined benefit pension plans ever since sponsors left the insured plan arena and established their own pension subsidiaries has been that these subsidiaries are financial companies while the parents have often been industrial operating companies. The traditional accounting for operating companies expects costs (including wages and employee benefits) to be stable in relation to product quantities 
and prices. As discussed in the previous section, actuaries devised ways to impose these operating company objectives on the accounting for the finance subsidiary.

\section{Accounting: earnings and balance sheet. Finance: returns and value}

An observation of accounting is that, in theory, the balance sheet and the income statement are redundant since each implies the other. ${ }^{13} \mathrm{~A}$ similar relationship exists in finance between portfolio returns and market value. This redundancy implies that analysts should be able to deduce the value of a business by review of either the earnings or the balance sheet. Given the limitations of theory, however, we are not surprised to learn that analysts attempt to value businesses through careful review of both presentations.

For operating companies, this use of both presentations adds to analyst understanding in part because neither is presented in market value terms. When, as is often the case, the analyst infers different values from different sources, s/he will often arrive at a valuation by a weighted judgmental process. At different times and in different industries one source or the other may dominate.

For financial entities, the tangible market value (assets less liabilities each at market value) may be arrived at relatively easily. ${ }^{14}$ The market value of the enterprise should exceed this baseline value due to franchise and option effects. ${ }^{15}$ For the special case where the financial entity is a defined benefit pension plan sponsored by an operating company, the positive franchise and option effects are properly attributed to the parent. Further, the negative option effects may be managed to a near zero value.

Thus the analysts should give great weight to the disclosed asset and liability values and virtually no weight to the pension expense. This would be consistent with existing pension financial theory. If corporate managers acted as though they believed that the analysts would act accordingly, we would expect observed behavior to align with pension theory. Analysts would adjust the corporate expense to ignore the pension component and would value the operating company without regard to the pension plan.

13 Barth, Beaver, and Landsman (1993)

14 For pension plans, these are revealed in the SFAS 87 footnote. 
Finally, the analysts would add the plan's tangible market value ("surplus" if positive, "deficit" if negative) to the operating company value.

Accordingly, the managers would invest entirely in fixed income assets (to maximize the potential tax arbitrage gain for shareholders) and would closely match the duration to the plan liabilities in order to minimize the value of embedded negative options.

All of this suggests strongly that the pension plan subsidiary is not viewed in the above fashion by analysts or else that the managers do not know that the analysts are using tangible market value. The managers must believe that analysts are giving substantial weight to the income effects of the pension plan.

In this paper we call the hypothesized behavior of the analysts the "opaque" view because they seem not to see and appreciate the tangible market value. We call the managerial behavior "contagious opacity" because it represents the managers reactions to the analysts inability to recognize the tangible asset value ${ }^{16}$. We also use the term contagious opacity to describe the potential behavior of the analyst who says to herself "I see that the appropriate value is the plan surplus (deficit) and I should ignore the pension income (expense), but my job is to deduce the value that the consensus will assign and I believe that the consensus assigns substantial weight to pension income."

\section{A thought experiment}

Suppose we establish a transparent box and place some publicly traded assets into it. We offer shares in the box. Not surprisingly, in an efficient setting, these shares sell at the net asset value of the assets in the box. Of course this is an open-end mutual fund and transparent accounting neither adds nor subtracts value from the assets in the box.

Next, suppose that the box is opaque. Periodically the box pays out its audited total return. Because the assets inside the box constitute a marketed portfolio, with some assumptions about information efficiency we can conclude that shares in this box will

Babbel (1999).

Actually, as discussed in Section V, I believe that they often follow a different discipline which would be disabled by transparent pension accounting. 
also sell for their net asset value even though the market cannot see what is in the box. Perfectly accurate and pertinent accounting is a sufficient replacement for transparency.

Next, suppose that the box invests in the S\&P 500 index portfolio, can borrow without limits at the risk-free rate ${ }^{17}$, and pays out each period the expected return on the S\&P 500. In order to maintain one unit of S\&P exposure, the box borrows (lends) the excess (shortfall) of the paid out expected return relative to the actual return. The unconditional expected net borrowing/lending position of the box is zero for any future date. Because the box is opaque, the market observes only the payout.

Assuming that the S\&P expected return is unvarying, the payout is a constant stream. Under these assumptions, the market can be expected to value the ownership of the payout stream as a riskless perpetuity:

Defining:

$\mathbf{r}=$ short term riskless rate of return

$\overline{\mathbf{q}}=$ expected return on equities $>\mathbf{r}$

The market value of the unit of S\&P in the box is equal to $\overline{\mathbf{q}} / \overline{\mathbf{q}}=1$ and the value of the payout stream is $\overline{\mathbf{q}} / \mathbf{r}>1$. In effect, opacity combined with unlimited zero-expectedvalue borrowing adds value.

To apply this experiment to the real world, we have to make a case for analysts who focus on earnings instead of tangible market values and for managers who respond to analysts. The accounting literature ${ }^{18}$ shows that accounting can fool enough of the people some of the time. The FASB has, in concept, endorsed a fully transparent model but it has been reluctant to apply it immediately. We must also explain why those

17 In order to rule out arbitrage opportunities, structures such as this are excluded from modern asset pricing theory. In other words, extrapolation from this example leads to impossible 18 perpetual money machines.

Section V. 
analysts who do see through the accounting cannot establish profitable arbitrage strategies.

We believe that the dissonance between theory and practice calls for an explanation not provided by the transparent financial models. Other than for their transparency, however, we find the arbitrage based arguments of the models compelling. Whether our explanation for the lack of reconciliation between theory and practice is valid is subject to empirical analysis and we outline an appropriate test ${ }^{19}$.

\section{How pensions compare/contrast with the thought experiment}

The purpose of the thought experiment is to highlight the intuition for the more detailed analysis developed in Sections III and IV. The complete opacity attributed to the black box above exaggerates the pension plan case. The footnotes to the audited financial statements provide the market values of the pension assets and a good approximation to the market values of the liabilities deemed to have accrued to date.

Additionally, the rates of liability discount and the expected return on assets are disclosed so that it is possible for investors to make their own adjustments. Amir and Benartzi (1998) find a weak positive connection between the expected return on assets and the actual asset allocation. They indicate that enforcement would make the relationship stronger and result in a fair presentation. Neither they nor the other relevant accounting literature question the systematic bias implied by the use of an expected return that includes an equity risk premium.

The black box does not allow for additions to assets and future payouts. Pension plans typically award new benefits and pay out old benefits each year and often receive new contributions from the plan sponsor. The model below takes account of these matters.

Pension plan demographics affect the real world as well. In our model below we assume that these are perfectly predictable. In this regard, we follow the precedents of the existing pension finance literature. Further in this tradition, we assume that the plan liabilities are bond-like and may be modeled as such.

19 Section VII. 


\section{Model Approach}

We contrast the financial (transparent) model of defined benefit pension plans and the actuarial (opaque). The transparent view implies that almost every plan should be invested entirely in fixed income securities; the opaque model encourages equity investments. With the opaque model, good things happen to managers who invest in equities. Under the transparent model, bad things would happen.

\section{Assumptions}

The models are based on the following assumptions:

A.1 The plan holds, as assets, a portfolio of marketed securities.

A.2 Plan liabilities are fixed cash flows without demographic uncertainty.

A.3 a) Transparency: the market values of pension plans accurately reflect the market value of assets and liabilities.

b) Opacity: the market values of pension plans are derived entirely from reported expenses (income).

A.4 The combination of collateral (plan assets), federal insurance and regulation, and very low probabilities of sponsor bankruptcy allow us to discount liabilities at or near riskless rates. ${ }^{20}$

A.3a defines the financial view of pension plans. A.3b defines the actuarial view.

\section{Definitions}

Consider a pension plan (subscript P) as a financial subsidiary (an annuity company) of an operating (subscript B) company. Let:

$\mathbf{A}_{\mathbf{P}, \mathbf{t}}=$ plan assets at time $\mathrm{t}$.

$\mathbf{L}_{\mathbf{P}, \mathbf{t}}=$ plan liabilities.

$\mathbf{E}_{\mathbf{P , t}}=$ plan surplus (deficit) $=\mathbf{A}_{\mathbf{P , t} \mathbf{t}}-\mathbf{L}_{\mathbf{P , t}}$

20 Gold (1989) discusses cases where this assumption is not supportable. 
so that $\mathbf{E}_{\mathbf{p}, \mathbf{t}}$ is the transparent value of the intermediary (tangible market value).

$\mathbf{A}_{\mathbf{B}, \mathbf{t}}=$ operating assets, valued at market. ${ }^{21}$

$\mathrm{L}_{\mathbf{B}, \mathbf{t}}=$ operating liabilities, valued at market.

$E_{B, t}=$ operating company equity $=A_{B, t}-L_{B, t}$

For the capital markets, let:

$\mathbf{r}=$ the one-period near riskless return.

$\overline{\mathbf{r}}=$ the near riskless periodic rate of return on the liabilities over their term (internal rate of return).

$\tilde{r}=$ the one-period stochastic total return on the liabilities.

$\tilde{\mathbf{q}}=$ the one-period stochastic rate of return on equity investment.

$\overline{\mathbf{q}}=$ the expected long-term rate of return on equity investment.

$\alpha=$ the fraction of assets invested in indexed equities, balance at the short term rate.

$\sim \sim$

$\mathbf{e}=\alpha \mathbf{q}+(1-\alpha) \mathbf{r}=$ one-period stochastic rate of return on an $\alpha$-weighted portfolio.

$\overline{\mathbf{e}}=\alpha \overline{\mathbf{q}}+(1-\alpha) \mathbf{r}=$ long-term expected periodic rate of return on an $\alpha$-weighted portfolio.

$\mathbf{M R V}_{\mathbf{t}}=$ market related value of assets which is often a trailing average of market values; a smoothed version of $\mathbf{A}_{\mathbf{P}, \mathrm{t}}$.

$\mathbf{C}_{\mathbf{t}}=$ cash contribution from the operating company to the plan at end of period.

$\mathbf{B}_{\mathbf{i}, \mathbf{t}}=$ benefit for participant $\mathbf{i}$ attributed to service up to time $\mathbf{t}$.

$\mathbf{P V D A}_{\mathbf{i}, \mathbf{t}}=$ present value at time $\mathbf{t}$ of a deferred annuity on behalf of participant $\mathbf{i}$.

21 Babbel (1999) identifies a franchise value and a default put value to the asset side of insurance company balance sheets. To the extent that these items apply to our entities, we ascribe them to the operating company. 
$\Delta \mathbf{P V B}_{\mathbf{t}}=\sum_{\mathrm{i}}\left(\mathbf{B}_{\mathbf{i}, \mathbf{t}}-\mathbf{B}_{\mathbf{i}, \mathbf{t}-1}\right) \mathbf{P V D A}_{\mathbf{i}, \mathbf{t}}=$ new liability attributable to the period $[\mathbf{t}-1, \mathbf{t}]$.

$\mathbf{P}_{\mathbf{t}}=$ pension benefits paid to participants at end of period.

$\mathbf{A M T}_{\mathbf{t}}=$ the one-period amortization of historic deviations between actual and assumed plan experience designed to drive $\mathbf{E}_{\mathbf{P}, \mathbf{t}}$ to zero over time.

\section{Pension Subsidiary Model}

\section{Structure}

Attach the pension plan subsidiary to the operating company following the augmented balance sheet concept introduced by Jack Treynor (Bagehot, 1972 and Treynor, Regan and Priest, 1978). The following is based on Figure 1 in the 1978 article:

\begin{tabular}{|l|l|}
\hline \multicolumn{2}{|c|}{$\begin{array}{c}\text { Augmented Balance Sheet } \\
\text { (at market value) }\end{array}$} \\
\hline \multicolumn{1}{|c|}{ Assets } & \multicolumn{1}{c|}{ Liabilities } \\
\hline $\mathbf{A}_{\mathbf{P}, \mathbf{t}}=$ Pension portfolio & $\mathbf{L}_{\mathbf{P}, \mathbf{t}}=$ Present value of pensions \\
\hline $\mathbf{A}_{\mathbf{B}, \mathbf{t}}=$ Corporate assets & $\mathbf{L}_{\mathbf{B}, \mathbf{t}}=$ Corporate liabilities \\
\hline & $\mathbf{E}_{\mathbf{t}}=\mathbf{E}_{\mathbf{P}, \mathbf{t}}+\mathbf{E}_{\mathbf{B}, \mathbf{t}}=$ Corporate equity \\
\hline
\end{tabular}

Thus the composite corporate entity is valued at (market capitalization):

$$
E_{t}=A_{B, t}-L_{B, t}+A_{P, t}-L_{P, t}
$$

We redesign this balance sheet along the lines of Mazzilli (1988):

\begin{tabular}{|l|l|}
\hline \multicolumn{2}{|c|}{$\begin{array}{c}\text { Consolidated Balance Sheet } \\
\text { (at market value) }\end{array}$} \\
\hline Assets & \multicolumn{1}{c|}{ Liabilities } \\
\hline$E_{\mathrm{P}, \mathrm{t}}=$ Annuity company equity & \\
\hline $\mathrm{E}_{\mathrm{B}, \mathrm{t}}=$ Operating company equity & $\mathrm{E}_{\mathrm{t}}=\mathrm{E}_{\mathrm{P}, \mathrm{t}}+\mathrm{E}_{\mathrm{B}, \mathrm{t}}=$ Corporate equity \\
\hline & \\
\hline & \\
\hline
\end{tabular}




\begin{tabular}{|c|c|}
\hline \multicolumn{2}{|c|}{$\begin{array}{c}\text { Balance Sheet - Annuity Company } \\
\text { (at market value) }\end{array}$} \\
\hline Assets & Liabilities \\
\hline $\mathbf{A}_{\mathrm{P}, \mathrm{t}}=$ Pension portfolio & $\mathrm{L}_{\mathrm{P}, \mathrm{t}}=$ PV pensions \\
\cline { 2 - 2 } & $\mathbf{E}_{\mathrm{P}, \mathrm{t}}=$ Annuity co. equity \\
\hline
\end{tabular}

\begin{tabular}{|c|c|}
\hline \multicolumn{2}{|c|}{$\begin{array}{c}\text { Balance Sheet - Operating Company } \\
\text { (at market value) }\end{array}$} \\
\hline Assets & Liabilities \\
\hline $\mathbf{A}_{\mathbf{B}, \mathrm{t}}=$ Corporate assets & $\mathbf{L}_{\mathrm{B}, \mathrm{t}}=$ Corp. liabilities \\
\cline { 2 - 2 } & $\mathbf{E}_{\mathrm{B}, \mathrm{t}}=$ Oper. co. equity \\
\hline
\end{tabular}

We ask how do the operating and annuity companies interact and which is responsible for what elements of pension plan operations and costs?

\section{Interactions}

As the employees accrue pension benefits, the operating company "buys" the benefits (market value $\triangle \mathrm{PVB}_{\mathbf{t}}$ ) from the annuity company which bears the responsibility for payment. Periodically, the operating company pays cash contributions $\left(\mathbf{C}_{\mathbf{t}}\right)$ to the annuity subsidiary in accordance with the rules of ERISA and the discretion of the plan's actuary working in cooperation with corporate management. The value $\mathbf{C}_{\mathbf{t}}-\Delta \mathbf{P V} \mathbf{B}_{\mathbf{t}}$ constitutes an infusion (drainage if negative) of capital into the annuity company by the operating company.

The accounting for the annuity purchases follows SFAS 87. As outlined in Appendix A, SFAS 87 uses the Projected Benefit Obligation (PBO) approach to attribute the accrual of benefits by individual employees to accounting periods. This means that benefits purchased in the current period are based on salaries expected to be earned in the future. An alternative Accumulated Benefit Obligation ( $A B O$ ) approach that does not anticipate future salary increases would be more in keeping with the modern finance view of pensions. Because this paper treats the definition of the liabilities as arbitrary (or at least exogenous), the $\mathrm{PBO} / \mathrm{ABO}$ distinction is moot. The annuity company is understood to be responsible for a given set of liabilities no matter how determined. ${ }^{22}$

\section{Costs - financial model}

Under the financial model, the consolidated marked-to-market cost of the plan is: 


$$
X_{t}^{f}=\left(L_{P, t}+P_{t}-L_{P, t-1}\right)-\left(A_{P, t}+P_{t}-C_{t}-A_{P, t-1}\right)
$$

Note that benefits paid to participants are redundant because assets and liabilities are simultaneously and equally reduced. As shown, a portion of the asset change $\left(\mathbf{C}_{\mathbf{t}}\right)$ is attributable to cash contributions made by the operating company to the annuity company. Similarly, part of the liability change $\left(\Delta \mathbf{P V B}_{\mathbf{t}}\right)$ flows the same way. Recognizing that that portion of the total pension plan expense is properly assigned to the operating company, we separately state the operating company portion and the annuity company portion of the pension cost:

$$
\begin{gathered}
\mathbf{X}_{t}^{f}=\mathbf{X}_{B, t}^{f}+\mathbf{X}_{P, t}^{f} \\
\mathbf{X}_{B, t}^{f}=\Delta P^{\prime} B_{t} \\
X_{P, t}^{f}=\left(L_{P, t}+P_{t}-\Delta P B_{t}-L_{P, t-1}\right)-\left(A_{P, t}+P_{t}-C_{t}-A_{P, t-1}\right)
\end{gathered}
$$

The change in assets not explained by assets contributed and assets paid out must be the investment return on the initial assets:

$$
A_{P, t}+P_{t}-C_{t}-A_{P, t-1}=\tilde{e} A_{P, t-1}
$$

and similarly for liabilities:

$$
L_{P, t}+P_{t}-\Delta P V B_{t}-L_{P, t-1}=\tilde{r} L_{P, t-1}
$$

We restate the annuity company loss (gain), i.e., its share of consolidated plan expense:

$$
\mathbf{X}_{\mathbf{P}, \mathbf{t}}^{\mathbf{f}}=\tilde{\mathbf{r}} \mathbf{L}_{\mathbf{P}, \mathrm{t}-1}-\tilde{\mathbf{e}} \mathbf{A}_{\mathbf{P}, \mathbf{t}-1}
$$

22 For a discussion of the economic relevance of the $\mathrm{PBO}$ and $\mathrm{ABO}$, see Bodie (1990). 
We note a special case where the plan is invested in liability-matching bonds, borrowing (lending) the plan deficit (surplus) at the short rate:

$\mathbf{X}_{\mathbf{P}, \mathbf{t}}^{\mathbf{f}}=\tilde{\mathbf{r}} \mathbf{L}_{\mathbf{P}, \mathbf{t}-1}-\tilde{\mathbf{r}}\left(\mathbf{A}_{\mathbf{P}, \mathbf{t}-1}-\mathbf{E}_{\mathbf{P}, \mathbf{t}-1}\right)-\mathbf{r} \mathbf{E}_{\mathbf{P}, \mathbf{t}-1}=\tilde{\mathbf{r}}\left(\mathbf{L}_{\mathbf{P}, \mathbf{t}-1}-\mathbf{A}_{\mathbf{P}, \mathbf{t}-1}\right)+(\tilde{\mathbf{r}}-\mathbf{r}) \mathbf{E}_{\mathbf{P}, \mathbf{t}-1}=-\mathbf{r} \mathbf{E}_{\mathbf{P}, \mathbf{t}-1}$

\section{Costs - actuarial/accounting model}

We want to show how the actuarial/accounting model differs from the financial model with attention paid to: 1) anticipation of returns to risk, and 2) smoothing to obscure the risk. In a sense these are two sides of the same coin and, assuming opacity, either side can appear to add value that does not exist in the transparent financial model. We will present the case wherein the value arises from the anticipation of returns to risk and where smoothing provides the mechanism necessary to facilitate the anticipation. An equal presentation might be made wherein the value arises from the smoothing implying that anticipation is the facilitating mechanism.

The value that appears to be induced by the opaque model arises in the context of a market with diversified investors with an equity risk premium attributable to the bearing of systemic (non-diversifiable) risk. This implies that fluctuations (zero-mean) in the expense (income) streams of the financial subsidiary that are orthogonal (zero-beta) to the market portfolio neither create nor destroy value. Elements in the expense (income) stream that do correlate with the market portfolio need to be discounted on a riskadjusted basis in order to measure present value.

With this in mind, we will rework the transparent cost equation by piecemeal substitution (identifying where the opaque model seems to add value) until we arrive at the opaque model of pension expense known as SFAS 87.

Assuming diversified investors and an equity risk premium strictly attributable to systemic risk implies that the certainty equivalent of all stochastic income variables is $\mathbf{r}^{23}$ Thus the ex-ante market value of $\mathbf{X}_{\mathbf{P}, \mathbf{t}}^{\mathbf{f}}$ is unchanged when we write (2) $\mathrm{as}^{24}$ :

23 This result may also be illustrated by hedging. 


$$
X_{P, t}^{f}=r L_{P, t-1}-r A_{P, t-1}=-r E_{p, t-1}
$$

which may be understood to mean that the risk-adjusted expense (income) of the pension subsidiary is identical to the short rate applied to the plan deficit (surplus) regardless of the asset allocation or liability duration as long as all of the assets and liabilities are defined in complete markets.

We revise the subsidiary expense using expected rather than risk-adjusted return:

$$
X_{\mathbf{P}, \mathbf{t}}^{\mathbf{a}}=\overline{\mathbf{r}} L_{\mathbf{P}, \mathbf{t}-1}-\overline{\mathbf{e}} \mathbf{A}_{\mathbf{P}, \mathbf{t}-1}
$$

where the new superscript indicates an actuarial rather than a financial value. This new expense is the pith of the opaque model. Below, we make some zero-mean zero-beta adjustments. These adjustments camouflage the process and allow it to achieve an accounting balance but no financial value is added or subtracted from this point onward.

We note that the changes in the market values of $\mathbf{L}_{\mathbf{P}, \mathbf{t}}$ and $\mathbf{A}_{\mathbf{P}, \mathbf{t}}$ over the period $[\mathbf{t}-1, \mathbf{t}]$ are always reconciled by the annuity company transparent expense, $\mathbf{X}_{\mathbf{P}, \mathbf{t}}^{\mathbf{f}}$, but that this is not the case when the expense is defined by $\mathbf{X}_{\mathbf{P}, \mathbf{t}}^{\mathbf{a}}$. These deviations are expected to average out to zero over time but, just to make sure that the accounting trues up over a defendable time frame (e.g., fifteen years), we (acting now as accountants) will identify the differences between the ex-post values of $\mathbf{X}_{\mathbf{P}, \mathbf{t}}^{\mathbf{f}}$ and $\mathbf{X}_{\mathbf{P}, \mathbf{t}}^{\mathbf{a}}$ that have accumulated over prior periods. Further, since the annuity company serves only the pension process, the accounting must also drive $\mathbf{E}_{\mathbf{p}, \mathbf{t}}{ }^{25}$ to zero over time.

24 (2) is the certainty equivalent of (1). For the remainder of this section, we adopt the convention of using the same notation on the left-hand side of equations for all members of a certainty equivalence set.

25 Adjusted for balance sheet accruals. 
The corrections to the forward accounting expense necessary to true up prior deviations and to eliminate the plan deficit (surplus) take the form of amortizations of these amounts over $n$ subsequent periods. ${ }^{26}$ This assures an asymptotic accounting balance at a horizon that is regularly extended. ${ }^{27}$ Thus:

$$
X_{P, t}^{a}=\bar{r} L_{P, t-1}+A_{M T}-\bar{e} A_{P, t-1}
$$

This representation produces a time series for $\mathbf{X}_{\mathbf{P}, \mathbf{t}}^{\mathbf{a}}$ with reduced volatility in comparison to the $\mathbf{X}_{\mathbf{P}, \mathbf{t}}^{\mathbf{f}}$ time series and with ultimately equal accounting value.

The actuarial methodology that was adapted in the process of developing SFAS 87 had been designed to provide a budgeting process for contribution flows from the operating to the annuity company. Smooth cash flows were a high priority of this design.

During the development of SFAS 87, many actuaries argued that (4) was too volatile. ${ }^{28}$ The historical actuarial approach smoothed the asset value before applying a rate of return. ${ }^{29}$ Thus the formula was adjusted to smooth it further:

$$
X_{P, t}^{a}=\bar{r} L_{P, t-1}+A_{M T}-\bar{e} M R V_{t-1}
$$

The differences between $\mathbf{M R V}_{\mathbf{t}-1}$ and $\mathbf{A}_{\mathbf{P}, \mathbf{t}-1}$ are also accumulated and their amortization becomes part of $\mathbf{A M T}_{\mathbf{t}} \cdot{ }^{30}$

$26 \mathrm{n}$ is a number defined as a weighted average of values each of which is usually in the range of $[5,15]$ years. The average amortization period depends on the plan's historical path.

27 The value of $n$ is adjusted each year to reflect emerging deviations. Thus, for an ongoing plan, $\mathrm{n}$ does not systematically shrink and the smoothing process is perpetuated. Upon plan termination, $n$ disappears so that all the accumulated deviations are accounted for at once.

28 Buck Consultants (1985) for example.

29 Hamilton, Jackson (1968)

30 Additionally, a corridor equal to $10 \%$ of the larger of $\mathbf{M R V}_{\mathbf{t}-1}$ and $\mathbf{L}_{\mathbf{P}, \mathbf{t}-1}$ is defined such that $\mathbf{A M T}_{\mathbf{t}-1} \equiv 0$ unless the absolute value of the accumulated deviations is greater than the 
Next some cosmetic (notational) changes need to be made: ${ }^{31}$

$$
\mathrm{X}_{\mathrm{P}, \mathrm{t}}^{\mathrm{a}}=\mathrm{iPBO}_{\mathrm{t}-1}+\mathrm{AMT}_{\mathrm{t}}-\mathrm{jMRV}_{\mathrm{t}-1}
$$

Finally we bring $\triangle \mathbf{P V B}_{\mathbf{t}}$ (renamed $\mathbf{S C}_{\mathbf{t}}$ ) back into the equation to reflect operating/annuity company consolidation:

$$
X_{t}^{a}=\mathrm{iPBO}_{\mathrm{t}-1}+\mathrm{SC}_{\mathrm{t}}+\mathrm{AMT}_{\mathrm{t}}-\mathrm{jMRV}_{\mathrm{t}-1}
$$

which is the SFAS 87 formula as shown in Appendix A.

\section{Costs - actuarial/accounting bias}

We now consider the difference between $\mathbf{X}_{\mathbf{P}, \mathbf{t}}^{\mathbf{a}}$ and $\mathbf{X}_{\mathbf{P}, \mathbf{t}}^{\mathbf{f}}$ to see whether these may be described as zero-mean zero-beta and thus without financial bias.

The difference $\Delta \mathbf{X}_{\mathbf{P}, \mathrm{t}}=\mathbf{X}_{\mathrm{P}, \mathrm{t}}^{\mathrm{a}}-\mathbf{X}_{\mathrm{P}, \mathrm{t}}^{\mathbf{f}}=(\overline{\mathbf{r}}-\mathbf{r}) \mathbf{L}_{\mathrm{P}, \mathrm{t}-1}-(\overline{\mathbf{e}}-\mathbf{r}) \mathbf{A}_{\mathrm{P}, \mathrm{t}-1}$. Since none of the terms are stochastic in their relation to the market portfolio in the period $[\mathbf{t}-1, \mathbf{t}]$, the difference may be described as zero-beta.

But the difference is not zero-mean. The accounting equation overstates the expense to the extent that $(\overline{\mathbf{r}}-\mathbf{r}) \mathbf{L}_{\mathbf{P}, \mathbf{t}}>0$ and it understates the expense to the extent that $(\overline{\mathbf{e}}-\mathbf{r}) \mathbf{A}_{\mathbf{P}, \mathbf{t}}>0$. The overstatement represents the difference that one usually expects to find between the internal rate of return on a liability-matching portfolio of bonds and the short rate. For the most part this overcharge is an artifact of SFAS 87 that cannot be

corridor amount. The purpose of the corridor is further to smooth expense by allowing relatively small amortizations of opposite sign to cancel out before recognition.

${ }^{31} \mathbf{i} \equiv \overline{\mathbf{r}} ; \mathbf{j} \equiv \overline{\mathbf{e}} ; \mathbf{P B O}_{\mathbf{t}-1}$ is a particular instance of the more general $\mathbf{L}_{\mathbf{P}, \mathbf{t}-1}$. It specifies that future salary increases are embedded in benefits attributed to the current period. 
directly altered by the plan manager ${ }^{32}$. It can, however, be neutralized on the asset side of the equation by adding liability-matching bonds to the assets of the plan while borrowing their cost. ${ }^{33}$

The understatement of the plan expense equal to $(\overline{\mathbf{e}}-\mathbf{r}) \mathbf{A}_{\mathbf{P}, \mathbf{t}}$ is generally under the direct control of the plan manager in two ways: first, by using accounting discretion with respect to selecting $\overline{\mathbf{e}}$ as discussed by Amir and Benartzi (1998); second by choosing the equity exposure percentage $\alpha$. The first represents a misapplication or lax enforcement of SFAS 87. The second is more significant because it represents a conceptual error in the financial framework that underlies SFAS 87.

The FASB has been moving towards a "fair value" approach that is likely, in the long run, to undo the bias in SFAS 87. It has developed a concept statement Exposure Draft (FASB No. 204-B, March 31, 1999) showing how "fair value" concepts may be employed to shift the accounting paradigm from valuation by history to valuation by arbitrage. It has also issued Preliminary Views (FASB No. 195-A, December 14, 1999) on the application of fair value to financial instruments and certain related assets and liabilities of corporations. Section V expands on these developments at the FASB.

\section{Value of the cost bias}

After hedging the overstatement of the expense due to liabilities ${ }^{34}$, the understated expense remains:

$$
(\overline{\mathbf{e}}-\mathbf{r}) \mathbf{A}_{\mathbf{P}, \mathbf{t}}=\alpha(\overline{\mathbf{q}}-\mathbf{r}) \mathbf{A}_{\mathbf{P}, \mathbf{t}}
$$

In perpetuity, the value of this bias equals:

32 The rate $\mathbf{r}$ is given by the market and the use of the rate $\overline{\mathbf{r}}$ is defined in SFAS 87 and backed by a powerful enforcement letter from the SEC (Schuetze, 1993).

33 Various ways of implementing this hedge are discussed by Gold and Peskin (1988).

34 The liability hedge (previous footnote) corrects the accounting bias, adds to earnings and reduces plan asset-liability risk. A corresponding asset hedge would eliminate equity investment and end the conflict between theory and practice that is the heart of this paper. 


$$
\alpha\left(\frac{\overline{\mathbf{q}}-\mathbf{r}}{\mathbf{r}}\right) \mathbf{A}_{\mathbf{P}, \mathbf{t}}=\alpha\left(\frac{\overline{\mathbf{q}}}{\mathbf{r}}-1\right) \mathbf{A}_{\mathbf{P}, \mathbf{t}}
$$

The partial derivatives with respect to $\alpha$ of the annual and perpetuity values are, respectively:

$$
\begin{gathered}
(\overline{\mathbf{q}}-\mathbf{r}) \mathbf{A}_{\mathbf{p}, \mathbf{t}} \\
\left(\frac{\overline{\mathbf{q}}}{\mathbf{r}}-1\right) \mathbf{A}_{\mathbf{p}, \mathbf{t}-1}
\end{gathered}
$$

If, for example, we take $\overline{\mathbf{q}}=12 \%, \mathbf{r}=6 \%$, then a $\$ 1$ shift of pension plan assets from cash to equity results in an earnings bias with a potential (fully opaque) perpetuity value of $\$ 1$ (pre-tax). After corporate tax at an assumed 35\% rate, market capitalization may be increased by $\$ .65$ for each dollar shifted. Alternatively, if we assume an after-tax price/earnings ratio of $30: 1$, market capitalization is inflated by $\$ 1.17$ [\$1(12\%-6\%)30(1-35\%)] for each \$1 shifted.

\section{Supporting Considerations}

In this section I briefly outline a transparent accounting method. We then review some of the explanations that practitioners offer for their investments in equities. We argue that these explanations are not sufficiently rebuked under opaque accounting but that we may reasonably believe that managers would alter their behavior if transparent accounting were the norm.

We then look at the earnings management literature and learn that earnings are valuerelevant for investors, that investors are often misled by managers who use accounting discretion to smooth and otherwise dress up earnings, and that accounting research is silent on the systemic bias in pension accounting. 
Lastly we look at FASB activity and see some progress towards transparent accounting. The FASB is seriously considering the use of fair value accounting for financial instruments. At the moment, their proposal in this area explicitly excludes SFAS 87 . If SFAS 87 were included we might well expect the financial press to follow the arguments of pension finance theory. This in turn would lead to persuasive arguments against pension plan equity investments that would be understandable and communicable among analysts, investors, financial planners and consultants.

\section{Transparent accounting}

Transparent accounting for a pension plan would follow the approach shown in equation (1) of Section IV.

Equation (1b), what SFAS 87 calls the service cost, is the fair value of benefits attributed to the current accounting period. It would be reported on the operating company's books as a component of employee compensation expense. Because it is a long duration discount variable, in a traditional defined benefit plan, it will be volatile with respect to interest rate changes. It will generally amount to a single-digit percentage of compensation and in the face of significant changes in long-term interest rates it might go up or down by as much as two percent of compensation from year to year.

If the corporation sponsored a cash balance plan and if the benefit attributed to the period for any employee equaled that year's compensation credit $^{35}$, then there would not be interest rate volatility.

Equation (1c), restated as equation (2), represents the change in tangible market value for the pension subsidiary or annuity company. Except when the probability of bankruptcy or asset reversion is not trivial, the market value of the company should reflect this change with a multiplier identical to one ${ }^{36}$. In order to facilitate this valuation, the market value of assets and liabilities should be presented in a pension balance sheet. The change in the tangible market value (annuity company net income) should

35 I.e., if an $\mathrm{ABO}$ approach to pension liabilities were employed. This approach is particularly appropriate in the cash balance case.

36 After accounting for taxes. 
be treated as "non-operating income" flowing into shareholders equity ${ }^{37}$ without appearing in the operating P\&L statement. ${ }^{38}$

Presented with pension plan information in this fashion, it is likely that analysts and investors would reach many of the same conclusions as do the financial researchers discussed in Section I.

\section{Opacity enables fables - practictioners' tales}

The opacity theory offered in this paper is a theory of enablement not of causation. What this means is that, absent opacity, the transparent financial theories would in all likelihood prevail over the common practices of the day. In this subsection we sketch the rationales commonly offered by corporate financial officers with pension plan responsibilities as well as by the actuaries and consultants who advise them.

What do pension plan managers tell themselves and their associates and constituents they are doing? Many would explain that they are maximizing long-term expected returns while tolerating acceptable levels of risk. When they invoke the long-term nature of the process, they are really making several possible arguments:

- In the long run equities are not as risky as they appear to be in the short run. This view is a proxy for a strong mean-reverting model or a shortfall model or for similar ideas that inhabit the actuarial (and popular) psyche. ${ }^{39}$ This view ignores arbitrage based arguments and generally supports perpetual money machines that may usually be reduced to "borrow at the risk-free rate and invest in equities and pay for liabilities with the profits".

- Even though equities are risky in the short run, the actuarial process is selfcorrecting and does not get far off course when market setbacks occur. The short-

Deferred taxes on this income (expense) should be taken into account.

The non-operating income approach is suggested by Knutson (1999).

Burrows (1999) says: "Any market downswing experienced in one generation will be offset by an upswing in later generations." Mr. Burrows has headed the Actuarial Standards Board and its project that led to Actuarial Standard of Practice 27 (ASOP 27). Key elements of ASOP 27 are outlined in Appendix D. ASOP 27 continues and formalizes the decades old actuarial practice of using the expected rate of return on plan assets to discount liabilities. 
term effects on plan assets are troubling but the impact is deferred and we usually catch up sooner or later. This is a combination of the long-term argument above and a reliance on the enabling actuarial technology. This combination can be no stronger than the long-term argument alone.

- Our real risk is underperforming our competitors and facing higher effective labor costs because we have not earned the equity premium. We can better tolerate the equity risk than we can the competitive risk.

If this were true and the enabling camouflage were not in place, then it could easily be countered by the Black argument: if your shareholders cannot figure out how to adjust your exposure to the equity market versus that of your competitors (i.e., they do not follow Tepper), then take the equity risk on your taxable balance sheet. In this instance it should be clear that such an exposure will not be camouflaged.

- We take the ERISA fiduciary responsibility seriously ${ }^{40}$. We understand that its version of the Prudent Man Rule tells us to diversify across asset classes as well as across individual securities. This is a misinterpretation of the rule. It is clear that a liability-matching bond portfolio meets ERISA fiduciary responsibilities as may many other all-fixed-income strategies.

- We do stochastic studies of our assets and liabilities ${ }^{41}$. These studies show us how assets, liabilities, expenses and various other measurement and control variables are likely to evolve over various time periods from five to thirty years. When we look at the results it is clear that equity exposure in the long run presents virtually no risk and that over shorter periods, we can live with the risks associated with our level of equity investment. As earlier, this is a combination of the long-term argument and a reliance on the enabling actuarial technology.

- Our pension plan is a profit center. We raise capital by promising benefits that an insurance company could provide. By running our own insurance company and investing in equities we profit. In a world where the annuity market is competitive,

40 McGill et al (1996) page 650 and following discuss ERISA diversification. 
shareholders of an operating business earn no special rewards for adding an annuity business to the product mix. The equity argument is the same perpetual money argument presented once again.

\section{Transparency disables fables}

Consider the senior manager who asks the company's auditors and actuaries what effect on earnings would occur if the plan were to reduce its policy ${ }^{42}$ exposure to equities. If the change in asset allocation were very large, it is almost certain that the manager would be told that the immediate effect would be a decrease in current earnings followed by lower expected earnings ever after. For a less substantial change in allocation (e.g., a reduction in equity exposure from $60 \%$ to $50 \%$ ), the manager would probably be told that the current earnings can be protected ${ }^{43}$ but that future earnings will very likely be reduced. When investor and analyst reactions to earnings are factored in, most managers are likely to continue the long term equity position of the plan even if they elect to reduce it tactically.

Now tell the senior manager that although equity returns are generally higher than those on fixed income, some of the rewards are likely to be shared by employees or taxcollectors. But the reported earnings will continue to be higher with equities and only very good equity returns will result in sharing with these other parties. The manager is still likely to conclude that this is a good arrangement.

Now explain the Tepper ${ }^{44}$ arbitrage argument to the manager. With lower equity exposure in the pension plan, taxable shareholders will be able to hold more equity in their personal portfolios and this is more tax-effective for them. The perceptive manager may ask whether the shareholder will be able to earn higher after-tax returns on a

$41 \quad$ McGill et al (1996) discusses such studies briefly beginning at page 574.

42 The expected long-term return on assets under SFAS 87 depends on the policy asset allocation which is determined infrequently. Interim (non-policy) allocations may vary due to market forces and tactical decisions.

43 The expected long-term rate of return on plan assets (what we have defined as $\mathbf{j}$ ) should be adjusted in accordance any changes in asset allocation policy or when the market environment for future returns changes. Actuaries have generally understood the phrase "expected long-term" to suggest that $\mathbf{j}$ should rarely be changed.

44 Unlike the Black version which has structural impediments and requires capitalization changes by the corporation, the Tepper arbitrage depends only on shareholder perception and revaluation. 
portfolio with identical volatility, because if that is true it seems to be a pretty good idea. Under today's accounting rules, however, the probable answer to that question is "no" because the volatility of the pension portfolio is being smoothed and the company stock is not trading as it would under the transparency assumption (i.e., like an operating company attached to a tax-sheltered mutual fund).

Now reconsider all three of the previous paragraphs in a world where the accounting procedure is transparent. The pension plan expense is based entirely on the new benefits accumulated by employees during the accounting period and the company maintains a tax-sheltered mutual fund whose asset and liability values are reported independently at market. Now the Wall Street Journal writes articles analyzing the company and the pension plan separately; The Journal and other business publications write articles explaining that investors should consider tax effects and volatility.

With such clean accounting, the articles would be easily written and understood. Now the senior manager will be told that earnings subject to a price-earnings multiple will not be affected when the equity exposure is changed. The manager, a shareholder as well, will understand that the pension plan is just one of the mutual funds $\mathrm{s} / \mathrm{he}$ owns and that it is special because it is tax-favored. Additionally, explain the employee call and the excise tax call and how their effects are accentuated by equity exposure and the manager should shortly conclude that equities are a poor pension investment choice.

Notice that if SFAS 87 were minimally amended to remove the bias that arises from the use of $\overline{\mathbf{e}}$ by requiring $\mathbf{r}$ and then smoothing $\tilde{\mathbf{e}}-\mathbf{r}$, we would still probably not have a clear basis upon which to articulate the Tepper-Black arbitrage in a persuasive fashion.

\section{Accounting literature}

The accounting literature is silent with respect to the bias discussed herein. The literature is not silent with respect to pension plans, nor with respect to accounting, nor with respect to bias. ${ }^{45}$ One article (Craig, 1999) very aptly observes that "Noise tends to

45 A search of $\mathrm{ABI} /$ Inform reveals 19435 articles with "pension" in the title or abstract, 43494 with the word "accounting" and 1077 with both. There are 5041 articles with "bias" in the title or abstract. There are 0 articles at the intersection of these terms. There are 49 with 
cancel out, bias does not." But he then tells us that "Noise is a statistical term referring to effects of random errors, which have a cumulative expected value of zero. Bias does not have an expected value of zero ... " This view is representative of the accounting literature in general. The earnings management literature diligently pursues evidence of accruals that are intentionally away from the mean.

Let us be clear as to exactly what the nature of my bias claim is. I contend that the substitution of $\overline{\mathbf{e}}$ for $\tilde{\mathbf{e}}$ is financially biased. The earnings management literature is presumptive with respect to the view that the deliberate misestimate of $\overline{\mathbf{e}}$ is biased ${ }^{46}$ but that a correct estimate of $\overline{\mathbf{e}}$ precludes bias.

SFAS 87 credits $\overline{\mathbf{e}}$ as the expected return on assets in each accounting period and defers (for amortization, i.e., forward averaging) the difference:

$$
\tilde{\mathbf{e}}-\overline{\mathbf{e}}
$$

If this difference were orthogonal to the market portfolio, we could invoke the Law of Large Numbers and agree that, on average, its value is indistinguishable from zero. But we (from a finance perspective) know that this is not the case. Actuarial and accounting theory, to date, appear to be insensitive to the difference. The entire pension accounting literature appears to take the actuarial view to the effect that there is not an economically important difference between the long-term average and the path that gets one there. Stated in traditional actuarial terms: if a variable is symmetrically distributed, the use of the mean is unbiased.

"pension" and "bias" but they refer to biases in the awarding of pensions not in the accounting. There are 206 with accounting and bias but these are focused primarily on earnings management.

46 Amir and Benartzi (1998), e.g. 
Earlier we invoked the financial equivalence between $\tilde{\mathbf{e}}$ and $\mathbf{r}$. If SFAS 87 were to credit $\tilde{\mathbf{e}}$, we would be on the way to transparent financial accounting. If SFAS 87 were to credit $\mathbf{r}$ and defer and amortize the difference:

\section{$\mathbf{e}-\mathbf{r}$}

we would not have full transparency but we would have a financially unbiased estimate. The disagreement may be stated simply: financially we identify a symmetry of valuation around the risk-free rate; in accounting and actuarial science we identify a symmetry around the expected return. As before, the key distinction is the power of arbitrage arguments in financial debate.

In an article written for actuaries interested in investment, Wendt (1999) explains an article by Bodie (1995) on the persistence of equity risk. Wendt shows that actuarial principles break down when the Law of Large Numbers is inapplicable or misapplied. No amount of forward averaging, and only excessively strong assumptions of meanreversion, can remove the financial bias that derives from the use of actuarial principles that average equity performance over time. Bodie and Wendt each use the price of insuring against equity underperformance as the arena to demonstrate the inappropriateness of trying to wring more than is possible from time diversification. The financial economics literature in this regard is traced by Bodie to Samuelson's (1963) simple but shockingly subtle paper.

How does this defense of the validity of the financial bias inherent in SFAS 87 support my claim with respect to the behavior of the equity analyst? In one sense the implications are clear. If the accounting and actuarial literature have missed the bias, why should we expect the analysts to unearth it?

Interestingly, this is too facile a leap. In fact, some analysts have an appreciation for the difficulty that is not directly reflected in the earnings management literature. Stone, Joy and Thomas (1995) report a survey of Certified Financial Analysts (CFA) who strongly support an accounting that is very close to what I have herein described as transparent. 
$21 \%$ of 350 random CFA designated analysts responded to the survey. A majority of the respondents favored an accounting system that would place the $A B O$ and the fair value of plan assets on the balance sheet and for an income equation that is much the equivalent of our equation (1).

So, if the analysts are keen on this issue, is the opacity claim without merit? That too might be too facile a leap. First, we would have to believe that the majority of the $21 \%$ of the random sample of analysts includes the marginal or consensus analyst. Second, that the consensus analyst is presently adjusting both the balance sheet and the income statement, ignoring the reported pension earnings and not assigning a multiple other than one to the growth of pension surplus. Third, that $s /$ he is immune to contagion and/or concludes that $\mathrm{s} /$ he represents the consensus view. Finally, we must believe that the corporate managers who make the asset allocation decisions for the pension plan are persuaded of this and that they are not themselves subject to contagious opacity.

\section{Earnings-management literature shows investors act on reported earnings}

The earnings management literature makes it clear that accounting earnings are an important part of the valuation performed by financial analysts and investors. In the language of the literature, earnings are "value-relevant." The literature also indicates that corporate managers believe that they can use accounting discretion to mislead their audiences over the short run.

We are not interested in earnings management per se since it may be defined (Healy and Wahlen, 1999) as manager use of "judgment in financial reporting and in structuring transactions to alter financial reports to either mislead ..." We are interested to learn that such efforts succeed, or that managers believe them to succeed, because investors place great emphasis on reported earnings. The authors note that "investors appear to view earnings as more informative than cash flow data."

Other researchers echo this last point often noting, however, that large abnormal accruals (accruals are defined as the algebraic excess of net income over cash flows) are often followed by inferior subsequent results and that negative abnormal accruals 
predict future positive results. This suggests investors follow earnings and are surprised when successful earnings management (over- or under-accrual) leads to reversals.

For our purposes we take two lessons from the earnings management literature. First, that investors and analysts make valuations that are highly dependent on reported earnings and, second, they are frequently unable to penetrate to the underlying economic realities.

We also note that the literature that addresses pension accounting makes no observations with respect to the systematic bias issue that we have raised here. This might indicate that all of the researchers are so aware of the bias implications of the smoothing process that they see no need to opine upon it. But Amir and Benartzi (1998) address the relationship between equity allocation and the expected long-term return on assets (i.e., $\alpha$ and $\overline{\mathbf{e}}-\mathbf{r}=\alpha(\overline{\mathbf{q}}-\mathbf{r}))$ without asking whether the use of any risk premium is appropriate. From the perspective of their paper, the issue is the difference between $\overline{\mathbf{e}}-\mathbf{r}$ and $\alpha(\overline{\mathbf{q}}-\mathbf{r})$ rather than the systemic difference between $\overline{\mathbf{e}}$ and $\mathbf{r}$ or the financially equivalent difference between $\overline{\mathbf{e}}$ and $\tilde{\mathbf{e}}$.

Barth, Beaver, Hand and Landsman (1999) and Barth, Cram and Nelson (1999) find that earnings (cash flow from operations plus accruals) is a better indicator of future earnings, cash flows and dividends than are cash flows alone. In other words accruals are value-relevant. But the sign of the coefficients on accruals are found to be negative while the signs on cash flows are consistently positive.

Chambers (1999) asks:

... whether investors misallocate invested capital away from firms that practice income-decreasing opportunistic earnings management and towards firms that practice income-increasing earnings management.

Accounting earnings are an important source of value-relevant information useful to investors' decisions about the composition of their investment portfolios. 
Chambers concludes:

Using a broad sample of NYSE, ASE and NASDAQ firms, I find significant positive abnormal returns from a hedge portfolio formed using an earnings-management trading rule. ... I demonstrate that these abnormal trading returns are most likely not the result of uncontrolled differential risk, but rather caused by market mis-pricing.

\section{The FASB process -yesterday, today and tomorrow}

Appendix A outlines the SFAS 87 pension expense equation. In that exercise and in its more recent activities (discussed below), the FASB may be seen to back away from transparency, generally in response to the concerns of statement preparers (corporate financial managers) and not in response to the preferences of equity analysts as reported by Stone, Joy and Thomas (1995).

SFAS 87 was developed during the 1980's out of the Projected Unit Credit (PUC) Actuarial Cost Method (ACM), one of several ACM's used by actuaries. Each of the ACM's had been designed to control a cash contribution budgeting process with almost no concern for accounting implications. The powerful smoothing techniques embedded in the ACM's made them natural favorites among statement preparers for use in accounting as well. The SFAS 87 predecessor, APB 8, permitted the use of many ACM's and generally equated cash contributions and expense.

SFAS 87 contains discussions about the process leading up to its adoption. Paragraph 116 tells of the debate with respect to the location (basic financial statements or footnotes) of the pension information. This amounts to a distinction between recognition and disclosure. The Board concluded:

116. ... Further, although the "equal usefulness" argument may be valid for some sophisticated users, the Board does not believe it holds for all or even most other users. Finally, if the argument were valid, the consequences of recognition would not be different from those of not recognizing but disclosing the same information; it is obvious from their arguments that many who assert that disclosure would be equally useful believe that recognition would have different consequences. [emphasis added] 
Note that, even after this observation, pension expense is recognized under SFAS 87 but pension assets and liabilities are merely disclosed in the footnotes. ${ }^{47}$

The lesson that we may take from this is that the presentation of information can be as or more important than its content. The fashion of today is to value companies more by multiples of earnings than by pension assets and liabilities that do not even make it out of the footnote and onto the balance sheet. Is it not reasonable to conclude that managers believe that their investors will be pleased by large equity exposure $(\alpha)$ and high expected returns $(\overline{\mathbf{e}})$ ?

In paragraphs 120 and 121, we learn that the Board acquiesced to understatement of the volatility inherent in the transparent accounting model:

120. The Board understands that measuring investments at fair value could introduce volatility into the financial statements as a result of shortterm changes in fair values. ${ }^{48}$ Some respondents described that volatility as meaningless or even misleading, particularly in view of the long-run nature of the pension commitment and the fact that pension investments are often held for long periods, thus providing opportunity for some gains or losses to reverse. ${ }^{49} \ldots$

121. The Board concluded that the difference between the actual return on assets and the expected return on assets ${ }^{50}$ could be recognized in net periodic pension cost on a delayed basis. ... That conclusion was based on (a) the probability that at least some gains would be offset by subsequent losses and vice versa and (b) respondents' arguments that immediate recognition would produce unacceptable volatility and would be inconsistent with the present accounting model. [emphasis added]

Note the phrase "the present accounting model." This is the model based on historic cost values. Currently an effort is underway at the FASB to supplant this accounting concept with the "fair value" concept discussed below.

47 When the plan assets fall below the $\mathrm{ABO}$, the difference is promoted to the liability side of the corporate balance sheet, but this is an unusual state.

48 This is consistent with our earlier observation that accounting rules applicable to an operating company are at odds with a transparent view of a financial subsidiary.

49 This argument is similar to that made by Burrows (1999) and at odds with Samuelson (1963).

$50 \tilde{\mathbf{e}}-\overline{\mathbf{e}}$ 
Volatility and delayed recognition of gains and losses are further discussed beginning at paragraph 173. In paragraph 178, we learn that:

178. The Exposure Draft [preceding the final version of SFAS] would have required use of the discount rate and the fair value of assets [i.e.,

$\overline{\mathbf{r}} \mathbf{A}_{\mathbf{P}, \mathbf{t}-1}$ instead of $\overline{\mathbf{e}} \mathbf{M R V _ { \mathbf { t } - 1 }}$ ] as the basis for calculating the return-onassets component of net periodic pension cost. Many respondents argued that the return-on-assets component so determined would create unacceptable volatility even if gains and losses were never amortized. The Board considered several approaches that would have further reduced volatility and concluded that the approach required by this Statement represents the best pragmatic solution.

Note that the basis in the Exposure Draft is very close to unbiased (the net bias after considering both assets and liabilities is $(\overline{\mathbf{r}}-\mathbf{r}) \mathbf{E}_{\mathbf{P}, \mathbf{t}-1}$ which is very small in comparison to the bias in the final Statement.

Note the resistance expressed to acknowledgement of the volatility inherent in equity investments. It is clear that many of respondents (most of whom were likely to be aligned with the preparers rather than the users of financial statements) perceived equity as a favored long-term investment (ignoring all arbitrage based indifference arguments) and volatility as an enemy. By prevailing, the respondents immunized themselves and their constituents against the theories of the financial economists.

Next we consider FASB's latest efforts. On March 31, 1999, FASB issued a revised Exposure Draft for a Proposed Statement of Financial Accounting Concepts (SFAC) Using Cash Flow Information and Present Value in Accounting Measurements. On December 14, 1999, FASB issued Preliminary Views on Major Issues Related to Reporting Financial Instruments and Certain Related Assets and Liabilities at Fair Value. Preliminary Views are a precursor to an Exposure Draft which in turn precedes an SFAS.

The Exposure Draft tells us that fair value is the objective for measuring the present value of future cash flows. Fair value is the market value where available and a 
reasoned estimate thereof when it is not. Paragraph 25 directly rebuts the approach adopted by actuaries in ASOP 27:

25. While the expectations of an entity's management are often useful and informative, the marketplace is the final arbiter of asset and liability values. Fair value represents a price and, as such, provides an unambiguous objective for the development of the cash flows and interest rates used in present value measurement. In contrast, the alternative measurements all accept an element of arbitrariness in the selection of an interest rate. For example, some might argue that an asset-earning rate is appropriate for cost-accumulation measurement of liabilities.

... an entity must pay the market's price when it acquires an asset or settles a liability in a current transaction, regardless of its intentions or expectations. For measurements at initial recognition or fresh-start measurements, fair value provides the most complete and representationally faithful measurement of the economic characteristics of an asset or a liability. [emphasis added].

But the Exposure Draft does not tell us where and when fair value measurement is required. Paragraph 13:

13. The Board also decided that this Statement will not specify when fresh-start measurements are appropriate. Accountants frequently face situations in which a change in an asset or liability can be recognized by either a fresh-start measurement or an adjustment to the existing amortization convention. The events and circumstances that prompt a fresh-start measurement vary from one situation to the next, and information about estimated future cash flows is sometimes part of the remeasurement determination. The Board expects to decide whether a particular situation requires a fresh-start measurement or some other accounting response on a project-by-project basis.

The Preliminary Views are a specific application of the Exposure Draft to a class of assets and liabilities that either are or bear a close relationship to financial instruments. If the Preliminary Views were to be adopted, assets and liabilities that have financial instrument properties would be carried at fair value. A fresh-start value would be measured with each financial statement and would not bear an amortizable relationship to any previous instances of the item in question. Additionally, the changes in fair value from one period to the next would be reported immediately in net income (paragraph 8c). 
Because most assets and liabilities already enter the books of account at fair value when their recognition stems from a transaction, the challenging issue for the FASB is the fresh-start remeasurement for financial instruments. Interestingly, the pension and other post-retirement benefits are already subject to annual remeasurement. But, according to paragraphs 37 and 41 of the Preliminary Views, they will be excepted:

37. Certain financial instruments are excluded from the scope of this Preliminary Views, including: ...

e. Employers' and plans' obligations for pension benefits ...

41. Employers' and plans' obligations for pension benefits ... are excluded for practical reasons. Some of these obligations can be especially complex, and accounting literature already requires periodic remeasurement of those obligations (albeit not at fair value).

\section{Counter Arguments}

The opaque model argues that managers enjoy expected equity returns without the attendant risk because investors and analysts do not see through the reported earnings. In this section we review three challenges to this assertion: 1) managers do not take full advantage of the opportunity to front load equity returns, 2) analysts have the means to see through the accounting, and 3 ) the accounting does not entirely obscure equity risk.

\section{SFAS 87 expected returns on assets do not fully adjust for equity premia}

Amir and Benartzi (1998) find that the relationship between equity allocation and expected return on plan assets is weak. They analyze the extreme deciles and deduce that the implied equity risk premium is only $67 \mathrm{bp}$. In other words, the slope of $\overline{\mathbf{e}}$ as a function of $\alpha$ is only $.67 \%$ despite typical empirical estimates of $(\overline{\mathbf{q}}-\mathbf{r})$ in the range of $5 \%$ to $6 \%$. This finding indicates that the earnings advantage that derives from using the expected return on equities is not being taken immediately. Managers who invest in equity and conservatively estimate $\overline{\mathbf{e}}$ expect $\mathbf{A M T}$ to have a negative (favorable) rather than zero mean. Amir and Benartzi also report that the expected return was not frequently updated from 1988 through 1994. 
To the extent that hypothesized managerial behavior depends exactly on the reported year-to-year earnings, these empirical results represent a challenge. But much of the story depends on the smoothing opportunities and much depends on longer term expected pension plan costs. Pension fund managers are fond of saying that they are long-term investors who hold equity because it substantially reduces the costs of their employee benefit plans over time. They invest confidently and substantially in equity knowing that short term fluctuations will be smoothed away by the actuarial/accounting process and that, if equity returns are indeed superior, the pension costs over the next several years will be reduced and corporate earnings will rise.

Thus managers look to the actual returns on equities over time (some positive part of which drips through the amortization process when the expected return is consciously conservative) as beneficial while they ignore the financial risks from which they are generally shielded. To some degree, the understatement of expected return premia noted by Amir and Benartzi is a mechanism for acknowledging that personal risk tolerance is not symmetric. By upwardly biasing the amortization of lagging returns, managers mitigate their risk associated with falling markets as distinct from the shareholders' risk associated with equity volatility.

\section{SFAS 87 disclosures are sufficient to approximate transparent expense}

The values of $\mathbf{A}_{\mathbf{P}, \mathbf{t}}$ and $\mathbf{L}_{\mathbf{P}, \mathbf{t}}$ are available in the SFAS 87 footnote and these are sufficient to allow analysts to make close approximations to the transparent accounting. Although these and other data useful for analyst decomposition of the pension subsidiary were not readily available prior to the adoption of SFAS 87, their subsequent availability has not led to changes in asset allocation consistent with the transparent financial pension theories. Equity allocation since adoption has actually increased somewhat, although that appears to be explained primarily by market performance.

The issue remains the inconsistency between the reported expense and the available market values. Until this is resolved (by transparent accounting), the theories of pension finance will not be allowed to inform the marketplace. 
May 30, 2000

\section{Multi-year beta}

In Section IV I asserted that none of the items in (4) were stochastic with respect to the contemporaneous market portfolio and thus were zero-beta. This is literally true with respect to each year's pension expense because any equity exposure in $\mathbf{A M T}_{\mathbf{t}}$ or $\mathbf{M R V}_{\mathbf{t}-1}$ has been resolved to a certainty as of $\mathbf{t}-1$. Further the stochastic experience in the period $[\mathbf{t}-1, \mathbf{t}]$ will enter into the values of $\mathbf{M R V}_{\mathbf{t}}$ through $\mathbf{M R V _ { \mathbf { t } + 4 }}$ and thus into the pension expense for periods ending at $(\mathbf{t}+1)$ through $(\mathbf{t}+5)$. The deviations between $\tilde{\mathbf{e}}_{\mathbf{P}, \mathbf{t}-1}$ and $\overline{\mathbf{e}} \mathbf{M R} \mathbf{V}_{\mathbf{t}-1}$ will enter into the $\mathbf{A M T}$ for periods beginning no earlier than $[\mathbf{t}, \mathbf{t}+1]$ and then only if the accumulated gains and losses fall outside of the $10 \%$ corridor.

It is easy to conclude that a return series that is uncorrelated with the market portfolio in each year is uncorrelated over longer periods. But this is not the case here because the return series is an artificial construct. If we were to look at the values of $\mathbf{e} \mathbf{M R V} \mathbf{t}_{\mathbf{t}-1}$ and e $\mathbf{A}_{\mathbf{P}, \mathbf{t}-1}$ over multi-year periods, we would find correlation (beta measured over $(\mathbf{m}>1)$ year periods would be a positive function of $\alpha$ and of $\mathbf{m}$ when $\mathbf{m}$ is inside the smoothing range).

The clues to the longer-term positive beta are available to a determined analyst. But the analyst so motivated to evaluate the multi-period beta of the returns on plan assets would certainly be using the market values of $L_{P, t}$ and $A_{P, t}$ to deduce the transparent state of affairs. Thus the existence of a measurable positive multi-year beta adds virtually nothing to the transparency/opacity debate.

The $10 \%$ corridor retards the rate at which observable beta arises over time. With small values of $\alpha$, the corridor may well be sufficient to suppress observable beta for decades. With larger $\alpha$, the market sensitivity of asset returns will manifest itself more rapidly. Thus the corridor serves to leverage the suppression of recognizable equity risk. 
This means that the degree of observable risk is no longer as linear as the definitions of $\overline{\mathbf{e}}$ and $\tilde{\mathbf{e}}$ would suggest.

The risk associated with equities is substantially, but not fully, suppressed under SFAS 87. The observable risk is a convex function of $\alpha$. This has some implications for a question not asked in this paper: if equity risk is so substantially suppressed by SFAS 87, why not invest the plan entirely in equities? There would appear to be larger reasons for sponsor reluctance to do so and we will leave this issue for subsequent research.

\section{Empirical Implications}

The empirical question of interest raised by the arguments presented herein is not "are pension plan asset allocations consistent with financial theory?" We know the answer to that is "no." The empirical question to be asked is "do investors use the transparent model or do they respond to earnings presentations?" A related, but not identical, question is "do managers behave as though they believe that investors follow reported earnings?" While we may not directly address the second question, we can specify empirical tests that help answer the first question and we may infer that, if investors do respond to earnings, managers will believe that they do. If investors see through to the transparent result, managers would be well-advised to learn this and exit the equity mutual fund business.

Further, if shareholders' views are transparent, managers should support changes to the accounting rules that will reinforce transparency and permit shareholders to understand manager strategies that take advantage of tax rules and embedded options. If, instead, shareholders follow a translucent model, managers may benefit from continued equity investment and resistance to accounting change.

We consider how investors incorporate pension plan information in their valuations of publicly traded companies. Under the transparent model, the market value of pension assets and liabilities enter into the market value of the corporation, $\mathbf{M V}$ : 


$$
\mathbf{M V}=\beta^{\prime} \mathbf{F}+\gamma_{1}\left(1-\tau_{\mathbf{c}}\right) \mathbf{A}_{\mathbf{P}}-\gamma_{2}\left(1-\tau_{\mathbf{c}}\right) \mathbf{L}_{\mathbf{P}}
$$

$\beta^{\prime} \mathbf{F}$ represents coefficients and factors that explain the cross-section of market values without explicit consideration of pensions and $\tau_{\mathbf{c}}$ is the rate of tax paid on corporate income. The transparent model implies that $\gamma_{1}$ and $\gamma_{2}$ both equal one. It is possible that $\gamma_{2}$ might equal one under opaque or translucent models as well. We will focus on the implications that may be derived from the treatment of the assets alone. A one-sided test of the hypothesis that $\gamma_{1}$ is significantly greater than one would be sufficient to reject the transparent model.

If we reject the transparent model, then we are encouraged to explore the opaque model. The opaque model says that investors value the pension earnings stream in lieu of the pension assets and liabilities:

$$
\mathbf{M V}=\beta^{\prime} \mathbf{F}+\gamma_{3}\left(1-\tau_{\mathbf{c}}\right) \frac{\overline{\mathbf{e}}}{\mathbf{r}} \mathbf{M R V}-\gamma_{4}\left(1-\tau_{\mathbf{c}}\right) \frac{1}{\mathbf{r}} \mathbf{A M T}-\gamma_{5}\left(1-\tau_{\mathbf{c}}\right) \frac{\overline{\mathbf{r}}}{\mathbf{r}} \mathbf{L}_{\mathbf{P}}
$$

As above, we will concentrate on the asset part of the equation and we begin by reformulating the asset part:

$$
\gamma_{3}\left(1-\tau_{\mathbf{c}}\right) \frac{\overline{\mathbf{e}}}{\mathbf{r}} \mathbf{M R V}=\gamma_{3}\left(1-\tau_{\mathbf{c}}\right) \frac{\overline{\mathbf{e}}}{\mathbf{r}}\left(\mathbf{A}_{\mathbf{P}}+\Delta\right)=\gamma_{31}\left(1-\tau_{\mathbf{c}}\right) \frac{\overline{\mathbf{e}}}{\mathbf{r}} \mathbf{A}_{\mathbf{P}}+\gamma_{32}\left(1-\tau_{\mathbf{c}}\right) \frac{\overline{\mathbf{e}}}{\mathbf{r}} \Delta
$$

which recognizes that the market related value of assets may be expressed as an offset from the market value. Note that $\overline{\mathbf{e}}, \mathbf{M R V}, \mathbf{A}_{\mathbf{P}}$ and $\Delta$ are all values that vary from company to company and appear in (or may be derived from) the financial statements ${ }^{51}$. A strong form of the opacity hypothesis would require that $\mathbf{r}$ be the riskless rate. A more realistic form would allow for greater values.

51 Barth, Beaver and Landsman (1993) shows how some variables may be derived even when they are not explicitly presented. 
$\gamma_{32}$ can tell us how much investors concentrate on earnings versus assets. If $\gamma_{32}$ is not significantly different from zero, then investors are ignoring the market-related value of pension assets, MRV. Alternatively, a finding that $\gamma_{32}$ is not significantly different from $\gamma_{31}$ implies that the market value of assets, $\boldsymbol{A}_{\mathbf{P}}$, is unimportant and that investors are looking to the market-related value of assets (i.e., the left-hand side of (7) applies). $\gamma_{31}>\gamma_{32}>0$ with significant inequalities implies a mixed or translucent approach to valuation.

The opaque model predicts that the left-hand of (7) applies and that $\gamma_{3}$ equals one. It may be supported by values of less than one. We may interpret such a fractional value of $\gamma_{3}$ as a revision to the discount rate :

$$
\gamma_{3}\left(1-\tau_{\mathbf{c}}\right) \frac{\overline{\mathbf{e}}}{\mathbf{r}} \mathbf{M R V}=\left(1-\tau_{\mathbf{c}}\right) \frac{\overline{\mathbf{e}}}{\mathbf{r} \div \gamma_{3}} \mathbf{M R V}
$$

This interpretation, however, loses its power as $\mathbf{r} \div \gamma_{3}$ approaches $\overline{\mathbf{e}}$.

\section{Persistent Mispricing}

How can this mispricing have persisted until now?

If the "true" value of the pension subsidiary, consistent with the transparent model, equals its after-tax assets less liabilities, then any other market value indicates mispricing. This mispricing arises from a consensus based on reported earnings. The consensus says that a portfolio of publicly traded equities in a pension plan is worth more than the same portfolio held elsewhere (even after accounting for taxes). Such a consensus mispricing should present an arbitrage opportunity for the investor who knows the "true" value. A few knowledgeable investors should profit and their actions should eliminate the arbitrage opportunity. Thus the mispricing should not persist. 
We suppose that the mispricing exists and we propose to profit from the arbitrage opportunity. We recall that the opportunity comes primarily from the difference between $\overline{\mathbf{e}} \mathbf{M R V}$ and $\mathbf{r} \mathbf{A}_{\mathbf{P}}$. In order to profit, we need to establish an arbitrage portfolio which:

- Is neutral with respect to valuation factors other than pension plan assets, i.e., $\mathbf{w}^{\prime} \mathbf{F}=\overline{0}$ where $\mathbf{w}$ is a vector of portfolio weights and $\mathbf{F}$ is a factor matrix including all valuation factors other than pension plan assets.

- Is neutral with respect to plan assets, i.e., $\mathbf{w}^{\prime} \mathbf{A}=\overline{0}$, where $\mathbf{A}$ is a matrix of plan assets by type and by firm.

- Minimizes the value of $\mathbf{w}^{\prime} \mathbf{V}$ where $\mathbf{V}$ is a firm by firm vector equal to $\mathbf{r} \mathbf{A}_{\mathbf{P}}-\overline{\mathbf{e}} \mathbf{M R V}$. Note that we are minimizing a negative value.

Now we wait until the "true" value prevails in the market. One way in which the values must true up is plan termination. Upon termination, $\mathbf{r A}_{\mathbf{P}}-\overline{\mathbf{e}} \mathbf{M R V}$ increases to a value of zero. For firms that we are long, this will cause us a loss; for firms we are short, this will profit us. Because we have minimized $\mathbf{w}^{\prime} \mathbf{V}$, we stand to gain more than we lose. But only when all the plans terminate and $\mathbf{w}^{\prime} \mathbf{V}$ increases to a zero value can we be assured of our arbitrage profit.

We might profit upon a change in regime. If and when the FASB adopts a transparent pension accounting model, $\mathbf{r} \mathbf{A}_{\mathbf{P}}-\mathbf{e} \mathbf{M R V}$ will effectively rise to a zero value for all firms at the same time. While this might happen fairly soon and while it may represent a genuine opportunity to profit from the existing bias, it does not answer the question that opened this section.

As long as the present regime prevails, we would-be-arbitrageurs may face an endless and expensive wait. Consider what happens if the accounting system remains unchanged while the size of pension portfolios increases relative to the size of the plan sponsors. We can expect that $\mathbf{A}_{\mathbf{P}}$ and $\mathbf{M R V}$ will increase and $\mathbf{r} \mathbf{A}_{\mathbf{P}}-\overline{\mathbf{e}} \mathbf{M R V}$ will 
become more negative and we will be losers. Our hoped-for future gains will then be larger but we may be unable to sustain our portfolio. This is comparable to the value investor who buys undervalued stocks only to discover that they can become more undervalued before they recover. The stocks may recover, but the investor may not. It is also similar to shorting a rational bubble. The hoped-for-gains when the bubble bursts may grow while the short investor goes bankrupt.

The rational bubble analogy is quite apt. The one-period expected return to a buyer during a bubble equals the cash flow received plus the end of period investment value. If the bubble persists, the buyer is rewarded in accordance with his expectations. An investor who shorts will lose what the buyer gains and unless the date of the bubble bursting is known in advance, the losses can overwhelm any investor with finite capital.

In the pension case, as in the rational bubble, the would-be-arbitrageur cannot force the correction to occur on a schedule that assures the success of the arbitrage.

An informative contrast may be struck between the potentially endless mispricing that derives from accounting that is systemically biased and the temporary mispricing that may be generated by deliberate earnings management. Chambers (1999) builds portfolios based on earnings management and generates abnormal risk-adjusted gains. This occurs because accounting is a self-correcting process and the deliberate misrepresentation of one period is generally corrected over a short forward period.

But, one might ask, is not the pension accounting also self-correcting? Does not the amortization of gains and losses provide the necessary self-correction? Interestingly, it does not. What the amortization does is to true up the difference between the actual and expected returns of the past. It does not limit the self-perpetuating bias about the future. As long as the pension plan and the accounting regime persist, there is a perpetuation of the forward bias created by the anticipation of equity returns without the appropriate charge for risks not yet borne.

\section{Conclusions}

I have made the following sequence of arguments: 
- In contrast to modern financial theory, pension assets are substantially invested in equities.

- The SFAS 87 formulation for pension expense includes a financial bias likely to lead to systematic overvaluation of corporations whose pension plans invest in equities.

- This bias, though not undetectable, seems to have gone undetected in the pertinent accounting literature. And even as FASB moves to remove the bias, it does not appear that the removal is prompted by awareness of the bias.

- The opacity that enfolds the bias may have a causative role in the determination of pension asset allocation as corporate financial officers enjoy the benefit of the equity premium while avoiding much of the concomitant risk.

- For the bias itself to induce equity investment, managers must believe that financial analysts and investors find reported earnings to be value-relevant. The accounting literature finds that earnings in general and pension earnings are value-relevant.

- Nonetheless, the SFAS 87 footnote provides sufficient information for analysts to unwind the bias by reference to the disclosed pension asset and liability values at fair value. While there is evidence that some analysts are capable of unwinding the bias, there is little reason to believe that the consensus analyst does so.

- The opacity is very likely to have an enabling role in the allocation of pension assets to equities. A variety of perceived advantages to equity investment can be refuted in a transparent accounting environment. Notably, the significant tax disadvantages of equity investing would be exposable in a persuasive fashion. Because the accounting is not transparent and because the bias is neither well-publicized nor well-understood, these exposures and corrections do not occur.

I propose an empirical approach to determining the degree to which the bias is undetected by the capital markets.

I propose transparent pension accounting. I believe that such an approach will pave the way for the lessons of the prior theoretical research to be made manifest to investors. Accounting for expense that directly reflects the difference in end-of-year market values of assets and liabilities is necessary to support the financial story telling that will make the financial theory digestible by investors and analysts. Consider, many financial 
planners are able to tell their constituent investors to adjust their taxable and taxsheltered portfolio allocations to achieve net tax benefits consistent with their general risk-return balance. When the corporate story is as easily told, I predict that the theories of the financial economists will be realized. 


\section{Appendices}

\section{A Statement No. 87 of the Financial Accounting Standards Board (FAS 87), Accounting for Pensions by Employers}

FAS 87 provides the standards of accounting for private employers who sponsor defined benefit pension plans. The priority of pension accounting is to recognize pension cost over the service period of each employee covered by the plan. This objective leads, in part, to the choice of an accrued benefit actuarial cost method since such methods do not spread costs over aggregations of employees. The chosen method is a modification of an earlier actuarial method often identified as Projected Unit Credit (PUC).

The Projected Unit Credit method assigns to each year of service for each employee a pro rata share of the benefit that will have been earned upon separation from service, reflecting an estimate of any past or future wages that may be taken into account by the defined benefit formula. If, for example, an actuary assumes that an employee, hired at age 35 will retire at age 65 and will have a pay history at age 65 that entitles him to an annual retirement benefit of $\$ 30,000$, the method will dictate that $\$ 1000$ of that benefit be allocated to each of the thirty years of service.

If that employee is now 50 years of age, the method will recognize $\$ 15,000$ of the projected $\$ 30,000$ benefit as having been accrued to date and will recognize an additional $\$ 1000$ to be earned in the current accounting year. The $\$ 15,000$ benefit, multiplied by an appropriate annuity factor and discounted for the period prior to the commencement of the benefit, becomes the Projected Benefit Obligation (PBO) attributable to this employee. The PBO for the plan will be the sum for all current participants of the plan including the remaining annuity value for all those no longer actively employed. The $\$ 1000$ of benefit to be allocated to the current period will also be multiplied and discounted by the same factors. The resulting value is called the Service Cost (SC) for this employee and will be aggregated across employees to yield the plan's Service Cost for this period. Using the language of traditional actuarial writings, 
the PBO would be called the Accrued Liability (AL) under the PUC method. The SC would be called the Normal Cost (NC) under the PUC method.

Under the traditional PUC method, the annual cost for the plan would then be determined as: $\mathbf{N C}+\mathbf{A M T}$, where the amortizations are periodic payments with a present value equal to the Unfunded Accrued Liability which is the difference between $\mathbf{A L}$ and the Actuarial Value of Assets (AAV): PBO-AAV. The AAV is called the Market Related Value of Assets (MRV) under FAS 87. The amortization amount for the current period would depend upon the history of events that created the divergence between the (AAV) and the (PBO). Such items as an existing difference at the commencement of the plan, or a difference created by changes to the benefit formula of the plan or to changes in actuarial assumptions, or to differences over time between actual and assumed experience (actuarial gain or loss) would be amortized over various fixed periods.

FAS 87 modifies this method in several ways:

- The amortizations in the traditional method include interest on the unfunded accrued liability in each amortization element. FAS 87 separates the interest component and applies it to the PBO and the MRV separately. The unfunded accrued liability arising from the initial application of FAS 87 and any changes therein attributable to changes in the plan formula or actuarial assumptions are spread (amortized) over time without interest. The gain or loss is accumulated (the asset component of gain and loss is included herein only after it has entered into the MRV) and when it exceeds an optional buffer zone known as a "corridor" it is spread over time without interest.

- The interest component applied to the PBO is computed using a discount rate identified as the "settlement rate". This same rate, designated $\mathbf{i}$ below is also used to compute the PBO itself and the SC. It is determined at each valuation date based on the returns available on high-quality fixed income securities or annuities. In the sense that it contains no equity risk premium and does not take the plan's asset allocation into account, it may be described as a nearly risk-free rate applicable 
to the liability term structure. ASOP 27 identifies this as a "prescribed rate" and exempts it from the general ASOP 27 rules pertaining to the selection of an investment return range.

- The interest component applied to the MRV is computed using an expected longterm rate of return on plan assets that is consistent with the ASOP 27 rules. This rate designated $\mathbf{j}$ below is generally left unchanged for several years.

The PUC formula may then be reconstituted as: $\mathbf{i P B O}_{\mathbf{t}-1}+\mathbf{S C}_{\mathbf{t}}+\mathbf{A M T}_{\mathbf{t}}-\mathbf{j} \mathbf{M R V _ { \mathbf { t } - 1 }}$. Herein, amortizations are without interest. Amortization of accumulated gains or losses only considers such gains or losses outside of the corridor. The asset component of gains and losses only recognizes the difference in actual versus expected return to the extent that the difference has been filtered through the averaging process used to develop the MRV. As in most ACM's, the special treatment of the divergence between asset assumptions and experience amounts to an extra degree of smoothing.

\section{B Excise Taxes on Assets Reverted to Plan Sponsors}

Since $1986^{52}$, an excise tax has been imposed on such reversions in addition to (and not deductible against, per IRC Section 275(a)6 applied to Chapter 43) the income tax. This tax has, since 1990 , been at the rate of $20 \%$ of reverted assets if a qualified replacement plan (typically a DC plan would replace a DB plan) is funded with not less than $25 \%$ of the surplus (the residual after settling plan liabilities), and at a $50 \%$ rate in the absence of such replacement.

The impetus for the inclusion of the excise tax was Senator Howard Metzenbaum (DOhio, 1977 - 1995) reacting to the reversion of excess plan assets by more than a few large and visible corporations in the early to mid 1980's. The result has been that substantial plan reversions by taxable corporations are rare.

$5210 \%$ excise tax on asset reversions, IRC Section 4980, added by Pub. L. 99-514, title XI, Sec. 1132(a), for reversions after December 31, 1985. Increased to $15 \%$ by Pub. L. 100-647, title VI, Sec. 6069(a), for reversions after December 31, 1988. Increased to $20 \%$ by Pub. L. 101-508, title, XII, Sec. 12001 which further provided a rate of $50 \%$ unless the employer used at least $20 \%$ of the otherwise revertible assets to fund immediate benefit increases or at least $25 \%$ to fund a qualified replacement plan, for reversions after September 30, 1990. 
To see why, consider a surplus of assets over the cost of settling liabilities equal to $\$ 1$ for a corporation in the $35 \%$ federal income tax bracket. If the $\$ 1$ is returned to the corporation directly, a 50\% excise tax is applied in addition to the $35 \%$ marginal income tax rate leaving $\$ .15$ after tax. If the employer elects to divert $\$ .25$ towards a qualified replacement plan, then the revertible amount is reduced to $\$ .75$ against which a $55 \%$ tax is imposed ( $20 \%$ excise plus $35 \%$ income) so that the after-tax return to the corporation is $\$ .3375$. Clearly the law intends to induce the latter choice if any reversion is to occur. The recovery of $\$ .3375$ may be compared to a recovery of $\$ .65$ before the addition of IRC Section 4980.

\section{PBGC Put and Excise Tax Call}

The passage of ERISA in 1974 established the PBGC which introduced federal guarantees for defined benefit pension plans that were unable to meet the promises made to plan participants. Sharpe (1976) characterized the existence of the PBGC guarantee as a put option. If the premium for the PBGC coverage is not properly determined, Sharpe concluded that corporations could maximize shareholder interests by a combination of higher pension liabilities (offered to employees in exchange for reductions in other compensation), lower pension assets (caused by deliberately smaller employer contributions) and investment in risky assets.

Since that time the PBGC has defended itself by successfully pursuing legislative action to raise premiums, to adjust premiums for risk (albeit inadequately), to require faster funding for poorly funded plans, to increase the amount and status of claims that the PBGC can make against the sponsor of a terminated plan, to restrict voluntary termination (put exercise) to plans that are sufficiently funded (thus the put must be outof-the-money when exercised by the sponsor) or to insufficient plans sponsored by "distressed" 53 employers. Nonetheless, for a distressed company with an underfunded defined benefit plan, the Sharpe PBGC put may provide an incentive for deliberately risky investment.

53 P.L. 99-514. Single-Employer Pension Plan Amendments Act of 1986 (SEPPAA) as part of the Consolidated Omnibus Budget Reconciliation Act. 
Prior to the enactment of the first of the Metzenbaum reversion excise taxes (Appendix B), overfunding of a plan, regardless of cause, was potentially beneficial to shareholders. As long as the recapture of such excess funding was subject only to income taxes at the corporate level, the existence of excess assets added to potential shareholder gains. As Tepper (1981) shows, if such an $\mathbf{E}_{\mathbf{p}}$ were invested in fixed income, shareholders gain; invested in equity, shareholders face a wash. With the advent of the excise tax, however, there exists a tax trap for highly overfunded plans. If the amount of excess is so large that it cannot be absorbed by the regular development of newly earned benefit accruals, it must ultimately be subjected to the excise tax upon termination at some later date $^{54}$. In effect, each plan is short an "excise tax call" option if its assets reach levels sufficiently in excess of liabilities.

Combining the long position in the Sharpe put and the short position in the excise tax call, there is a sinusoidal curve to the value of $E_{p}$ (picture a sine function from $-\pi / 2$ to $+\pi / 2$ ). As the assets fall well below the level of the liabilities, the put increases in value and the PBGC shares in the marginal downside more than it does in the marginal upside resulting in the convex portion of the sinusoid. As the assets rise well above the liability level, the present value of future excise taxes grows in a fashion that creates the concave portion of the sinusoid.

\section{Actuarial Standard of Practice No. 27, Selection of Economic Assumptions for Measuring Pension Obligations}

Adopted by the ASB in December, 1996, ASOP 27 supercedes ASOP 4 with respect to economic assumptions. Generally, economic assumptions include discount rates, investment returns, inflation, compensation scales and related factors. They may be distinguished from noneconomic (demographic) assumptions relating to rates of death, disability, termination of employment, retirement, marriage, etc.

For the purposes of this paper, Section 3.6 Selecting an Investment Return Assumption and a Discount Rate is most relevant. Sections 3.5 Selecting an Inflation Assumption

54 This is not to say that this is inescapable. A company in such a position may get better value for its surplus by using it to pay for post-retirement health care costs using IRC Section 420 or it may acquire or be acquired by a company with an underfunded plan, etc. 
and Section 3.7 Selecting a Compensation Scale are pertinent to selection of rates of return used in SFAS 87.

Section 3.6 states in part that "The discount rate is used to determine the present value of expected future plan payments. Generally, the appropriate discount rate is the same as the investment return assumption. But for some purposes, such as SFAS 87 or unfunded plan valuations, the discount rate may be selected independently of the plan's investment return assumption, if any."

Section 3.62 Constructing the Investment Return Range details two example methods:

a. Building-Block Method - after identifying asset classes and, for each such class, estimating real returns and inflation, "compute an average, weighted real-return range reflecting the plan's expected asset class mix; and ... combine [this] ... with the expected inflation range."

b. $\quad$ Cash Flow Matching Method - "Under the cash flow matching method, the expected future investment return range is viewed as the combination of (i) the internal rate of return on a bond portfolio [of noncallable, high-quality corporate or U.S. government bonds] with interest and principal payments approximately matching the plan's expected disbursements, and (ii) a risk adjustment range." The risk adjustment range should reflect "expected future plan investments in equities or other asset classes besides high-quality bonds."

Clearly, the prescription given by ASOP 27 is that the equity premium (or other risk premia) is to be included in the discount rate when the plan is anticipated to invest in equities and other risky assets. In the present environment, the equity risk premium amounts to several percent per annum and equity allocations frequently represent a majority or near majority of plan assets. Thus, for such plans today, ASOP 27 holds that use of the risk-free rate is outside of the actuarial standard of practice. 


\section{References}

Actuarial Standards Board, Actuarial Standard of Practice No. 27, "Selection of Economic Assumptions for Measuring Pension Obligations", December 1996

American Council of Life Insurance (ACLI), "Life Insurance Fact Book", 1998.

Amir, E., and Benartzi, S., "The Expected Rate of Return on Pension Funds and Asset Allocation as Predictors of Portfolio Performance", The Accounting Review, Vol. 73, No. 3, July 1998.

Amir, E., and Benartzi, S., "Accounting Recognition and the Determinants of Pension Asset Allocation", Journal of Accounting, Auditing \& Finance, Vol. 14, No. 3 (New Series), Summer 1999.

Babbel, D., "Components of Insurance Firm Value, and the Present Value of Liabilities", Investment Management for Insurers (Babbel, Fabozzi, eds.), Frank J. Fabozzi Associates, Publishers, 1999, chapter 2.

Barth, M. E., Beaver, W. H., Landsman, W. R., "A Structural Analysis of Pension Disclosures Under SFAS 87 and Their Relation to Share Prices", Financial Analysts Journal, Jan.-Feb. 1993.

Barth, M. E., Cram, D. P., Nelson, K. K., "Accruals and the Prediction of Future Cash Flows", Working Paper, Stanford University, Nov. 1999.

Barth, M. E., Beaver, W. H., Hand, J. R. M., Landsman, W. R., "Accruals, Cash Flows, and Equity Values", Working Paper, Stanford University, July 1999.

Black, F., "The Tax Consequences of Long-Run Pension Policy", Financial Analysts Journal, July-August 1980, pp. 21-30.

Bodie, Z. "On the Risk of Stocks in the Long Run", Financial Analysts Journal May-June 1995.

Bodie, Z. "Shortfall Risk and Pension Fund Asset Management", Financial Analysts Journal May-June 1991.

Bodie, Z., "The ABO, the PBO and Pension Investment Policy", Financial Analysts Journal Sept.-Oct. 1990.

Bodie, Z. Light, J., Mprck, R. and Taggert Jr., R., "Funding and Asset Allocation in Corporate Pension Plans: An Empirical Investigation", Issues in Pension Economics (Bodie, Shoven, Wise, eds.), University of Chicago Press, 1987, pp. 15-44. 
Buck Consultants, "Buck Criticizes FASB Exposure Draft on Pension Accounting", For You Information, June 21, 1985.

Bulow, J., Scholes, M. "Who Owns the Assets in a Defined-Benefit Pension Plan?", Financial Aspects of the United States Pension System (Bodie, Shoven, eds.), University of Chicago Press, 1983, pp. 17-36.

Burrows, E. E., "A Cash Balance Solution for Social Security”, Enrolled Actuaries Report, May 1999

Craig, T. R., "Five Important Properties of Accounting Numbers", The CPA Journal, 69(5), pp. 60-61, May 1999.

Chambers, D. J., "Earnings Management and Capital Market Misallocation", Working Paper, University of Illinois at Urbana-Champaign, Dec. 1999.

Dreher, W. A., "Gain and Loss Analysis for Pension Fund Valuations", Transactions of the Society of Actuaries (TSA) No. 11 (1960), pp. 588-635

Financial Accounting Standards Board, Financial Accounting Standard No. 87, "Employers' Accounting for Pensions", December 1985

Financial Accounting Standards Board, Exposure Draft (Revised), Proposed Statement of Financial Accounting Concepts, "Using Cash Flow Information and Present Value in Accounting Measurements", No. 195-A, March 31, 1999.

Financial Accounting Standards Board, Preliminary Views "on major issues related to Reporting Financial Instruments and Certain Related Assets and Liabilities at Fair Value ", No. 204-B, December 14, 1999.

Friedman, B., "Pension Funding, Pension Asset Allocation and Corporate Finance: Evidence from Individual Company Data", Financial Aspects of the United States Pension System (Bodie, Shoven, eds.), University of Chicago Press, 1983, pp. 107152.

Gold, J., "Indebtedness as a Model for Deferred Liability Accounting", Comments to the Financial Accounting Standards Board, 1989.

Gold J. and Peskin, M. W., "Longing for Duration", Financial Analysts Journal, Nov.-Dec. 1988.

Hamilton, J. A., and Jackson, P. H., "The Valuation of Pension Fund Assets", TSA No. 20 (1968), pp. 386-417.

Harrison, J. M. and Sharpe, W. F., "Optimal Funding and Asset Allocation Rules for Defined-Benefit Pension Plans", Financial Aspects of the United States Pension System (Bodie, Shoven, eds.), University of Chicago Press, 1983, pp. 91-105. 
Healy, P and Wahlen, "A Review of the Earnings Management Literature and its Implications for Standard Setting", Accounting Horizons, Vol. 13, No. 4, December 1999, pp. 365-383

Knutson, P., Quoted in an article by Anand, V., "Question of Earnings: Regulators Reconsider FAS 87; Hefty Pension Surpluses Cause Concern About Interpreting Bottom Lines", Pensions and Investments, Oct. 4, 1999.

Mazzilli, P., "The Pension Plan as a Subsidiary", Morgan Stanley Pension Issues and Insights, August 1988.

McGill, D. M., Brown, K. N., Haley, J. J. \& Schieber, S. J., "Fundamentals of Private Pensions, Seventh Edition", Pension Research Council, The Wharton School of the University of Pennsylvania, University of Pennsylvania Press, 1996

Samuelson, P. A., "Risk and Uncertainty: A Fallacy of Large Numbers", Scientia, AprilMay 1963.

Schuetze, W. Letter from SEC to FASB Emerging Issues Tax Force, Sept. 22, 1993.

Sharpe, W. F., "Corporate Pension Funding Policy", Journal of Financial Economics 3, June 1976, pp. 183-193

Stone, K. E., Joy, D. W., Thomas, C. J., "Opinions of Financial Analysts on Accounting for Defined Benefit Pension Plans.", Journal of Applied Business Research, 11(3), pp. 65-73, Summer 1995.

Tepper, I., "Taxation and Corporate Pension Policy", Journal of Finance 36-1, March 1981, pp. 1-13.

Treynor, J. L. (using pseudonym, Walter Bagehot), "Risk and Reward in Corporate Pension Funds", Financial Analysts Journal, January-February 1972, pp. 80-84.

Treynor, J. L., Regan, P .J., Priest, W. W., "Pension Claims and Corporate Assets", Financial Analysts Journal, May-June 1978, pp. 84-88.

Trowbridge, C. L., "Fundamentals of Pension Funding”, TSA No. 4 (1952), pp. 17-43

Wendt, R. Q., "An Actuary Looks at Financial Insurance", Risks and Rewards, No. 32, March 1999. 